\title{
Characterization Results for 106-AN Grout Produced in a Pilot-Scale Test
}
R. O. Lokken
S. E. Palmer
L. M. Bagaasen
C. M. Anderson
P.F.C. Martin

June 1993

Prepared for the U.S. Department of Energy under Contract DE-AC06-76RLO 1830

Pacific Northwest Laboratory

Operated for the U.S. Department of Energy

by Battelle Memorial Institute 


\title{
DISCLAIMER
}

This report was prepared as an account of work sponsored by an agency of the United States Government. Neither the United States Government nor any agency thereof, nor Battelle Memorial Institute, nor any of their employees, makes any warranty, expressed or implied, or assumes any legal liability or responsibility for the accuracy, completeness, or usefulness of any information, apparatus, product, or process disclosed, or represents that its use would not infringe privately owned rights. Reference herein to any specific commercial product, process, or service by trade name, trademark, manufacturer, or otherwise does not necessarily constitute or imply its endorsement, recommendation, or favoring by the United States Government or any agency thereof, or Battelle Memorial Institute. The views and opinions of authors expressed herein do not necessarily state or reflect those of the United States Government or any agency thereof.

\author{
PACIFIC NORTHWEST LABORATORY \\ operated by \\ BATTELLE MEMORIAL INSTITUTE \\ for the \\ UNITED STATES DEPARTMENT OF ENERGY \\ under Contract DE-AC06-76RLO 1830
}

Printed in the United States of America

Available to DOE and DOE contractors from the

Office of Scientific and Technical information, P.O. Box 62, Oak Ridge, IN 37831;

prices available from (615) 576-8401. FTS 626-8401.

Available to the public from the National Technical Information Service, U.S. Department of Commerce, 5285 Port Royal Rd., Springfield, VA 22161. 
PNL-8655

UC -510

CHARACTERIZATION RESULTS FOR 106 -AN GROUT

PRODUCED IN A PILOT-SCALE TEST
R. 0 . Lokken
L. M. Bagaasen
P. F. C. Martin
S. E. Palmer
C. M. Anderson

June 1993

Prepared for

the U.S. Department of Energy

under Contract DE-ACO6-76RLO 1830

Pacific Northwest Laboratory

Richland Washington 


\section{SUMMARY AND CONCLUSIONS}

The Grout Treatment Facility (GTF) at Hanford, Washington, will process the low-level fraction of selected double-shell tank (DST) wastes into a cementitious waste form. This facility, which is operated by Westinghouse Hanford Company (WHC), mixes liquid waste with cementitious materials to produce a waste form that immobilizes hazardous constituents through chemical reactions and/or microencapsulation. Over one million gallons of phosphate/sulfate waste were solidified in the first production campaign with this facility.

The next tank waste scheduled for treatment is 106-AN (the waste from Tank 241-AN-106). After laboratory studies were conducted to select the grout formulation, tests using the 1/4-scale pilot facilities at the Pacific Northwest Laboratory (PNL) were conducted as part of the formulation verification process. The major objectives of these pilot-scale tests were to determine if the proposed grout formulation could be processed in the pilotscale equipment, to collect thermal information to help determine the best way to manage the grout hydration heat, and to characterize the solidified grout.

Two molds were constructed to accomplish these goals. The first mold was designed to produce a temperature gradient in the grout as it cured to determine the effects of curing temperature on the final properties of the grout. The second mold was designed to simulate pouring grout in $2-\mathrm{ft}$ lifts. The main grout production run filled the first mold and the first of four lifts in the second mold. Over $2000 \mathrm{gal}$ of grout were processed during $3.5 \mathrm{hr}$ of production time during the main pour. Three additional pours, each consisting of $350 \mathrm{gal}$. were conducted at one-week intervals to complete the second mold. The grout in the main run and the second and third lift pours was produced by mixing simulated 106-AN tank waste with dry blend consisting of 14 wt\% attapulgite clay, 20 wt\% type I/II Portland cement, and 66 wt\% class $F$ fly ash at a mix ratio of 8.7 pounds per gallon (lb/gal). A dry-blend composition of 11 wi\% attapulgite, 20.7 wt\% type I/II Portland cement, and 68.3 wt\% class F fly ash with a mix ratio of $8.41 \mathrm{~b} / \mathrm{gal}$ was used for the fourth lift. 
The grout produced with a dry-blend formulation consisting of 14 wt\% attapulgite clay, 20 wt\% type I/II Portland cement, and 66 wt\% class F fly ash showed significant shear thickening and had calculated critical flow rates (CFR) at the pipe discharge that were above the criterion value of 60 gallons per minute $(\mathrm{gpm})$. Slight modification of the dry-blend formulation to $11 \mathrm{wt} \%$ attapulgite, 20.7 wt\% type I/II Portland cement, and 68.3 wt\% class F fly ash reduced the critical flow rate to below $40 \mathrm{gpm}$. Other than the critical flow rate concerns, both formulations tested were readily processed by the pilotscale equipment.

Five cores, two from the lift mold and three from the gradient mold. were obtained and samples were tested for unconfined compressive strength, bulk density. ANS 16.1 leachability, and Washington Department of Ecology (WDOE) corrosivity test. The results of these tests on samples cured about 6 months are summarized below: '

- The compressive strength of the 106-AN pilot-scale grout cores averaged 899 psi. with a low of 602 psi and a high of 1438 psi.

- There were no significant differences in the strength of samples from the lift interfaces versus samples from the middle of the lifts.

- Compressive strengths were larger for samples from near the outter surface and from the center of the gradient mold.

- The nitrate and nitrite leachability indices of the 106-AN pilot-scale grout cores averaged 6.4 and 7.3 , respectively. The differences are likely caused by a conversion of nitrite to nitrate during curing.

- The leachability indices were smaller for samples taken at the lift interfaces than for samples from the center of the lifts.

- Leachability indices were larger from samples from near the surface and from the center of the gradient mold.

- The 106-AN pilot-scale grout samples contained an average of about $3 \%$ more porosity than the laboratory-produced grout samples. based on density differences.

- The 106-AN pilot-scale grout is not corrosive when subjected to the WDOE corrosivity test. 


\section{CONTENTS}

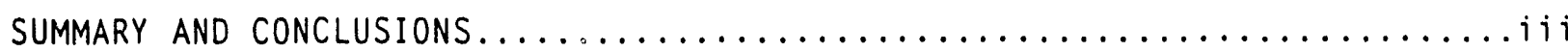

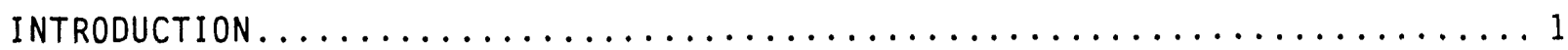

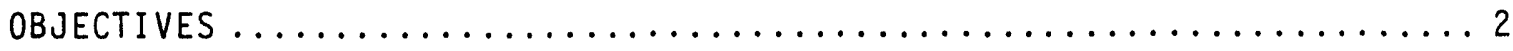

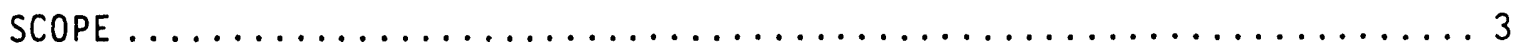

FACILITY DESCRIPTION..................................... 5

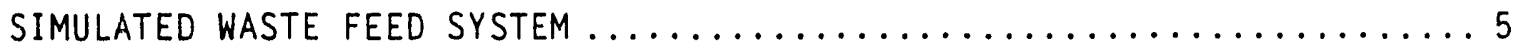

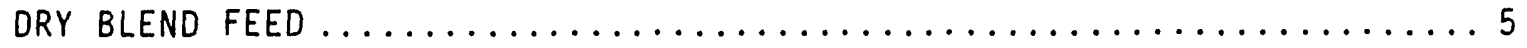

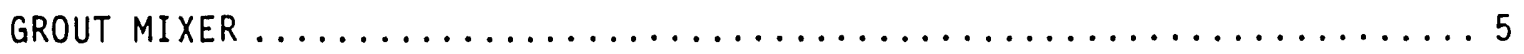

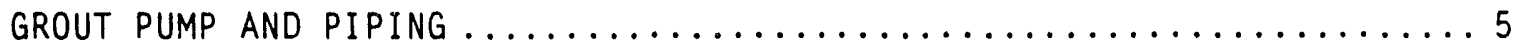

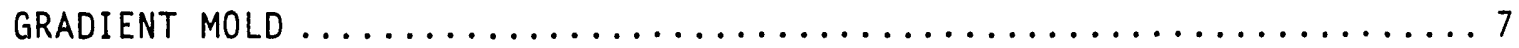

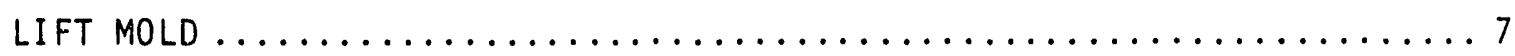

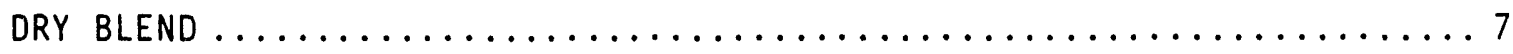

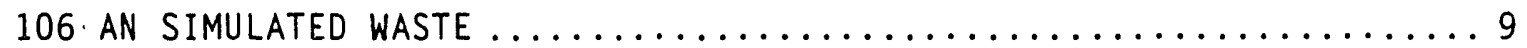

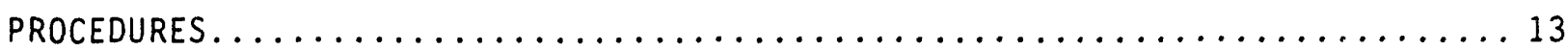

CORE DRILLING AND SAMPLE PREPARATION $\ldots \ldots \ldots \ldots \ldots \ldots \ldots \ldots \ldots \ldots \ldots$

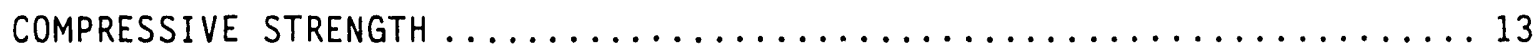

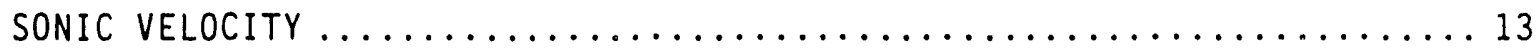

AMERICAN NUCLEAR SOCIETY (ANS 16.1 ) LEACH TEST $\ldots \ldots \ldots \ldots \ldots \ldots \ldots 14$

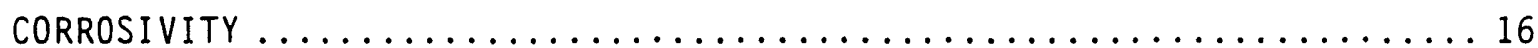

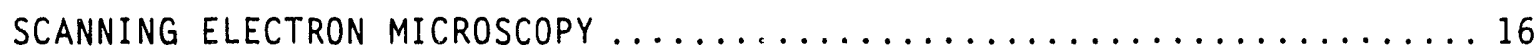

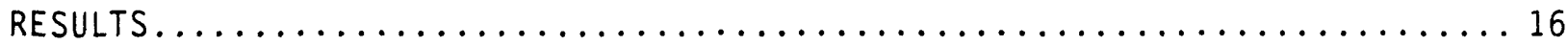

COMPRESSIVE STRENGTH, BULK DENSITY, AND SONIC VELOCITY $\ldots \ldots \ldots \ldots \ldots 17$

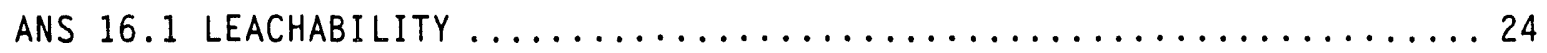

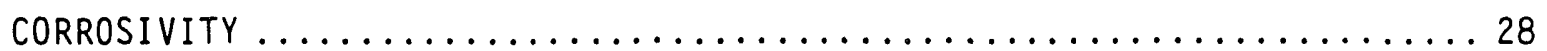

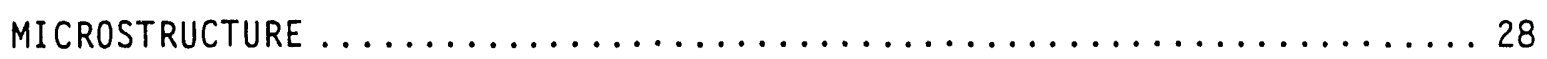

REFERENCES........................................... 33 


\section{FIGURES}

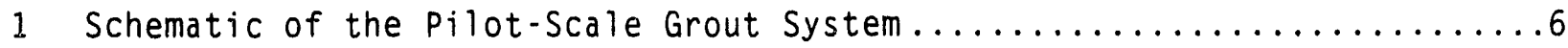

2 Compressive Strength of 106-AN Grout Samples from the Lift Mold......20

3 Approximate Average Temperatures for Pilot-Scale 106-AN Grout Cores

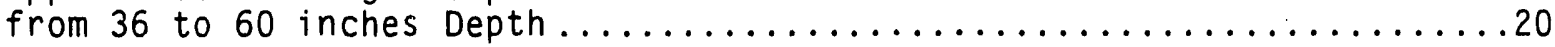

4 Average Compressive Strengths for 106-AN Grout Samples as a Function of Distance from the Gradient Mold Surface ........................

5 Correlation Between Sonic Velocity and Compressive Strength of 106-AN

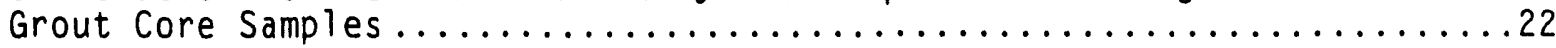

6 Correlation Between Sonic Velocity and Bulk Density of 106-AN Grout

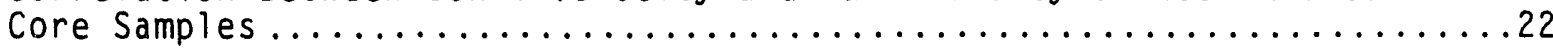

7 Nitrate Leachability Indices of 106-AN Grout Samples from the Lift

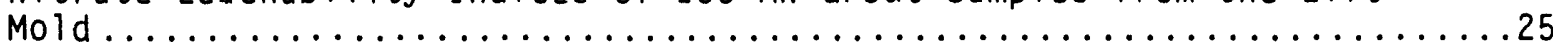

8 Nitrate Leachability Indices for 106-AN Grout Samples as a Function

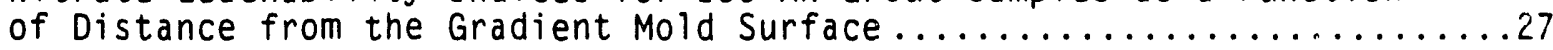

9 Environmental Scanning Electron Micrographs of 106-AN Pilot-Scale Grout Core Sample: 0 btained 4 -in. from the Edge of the Gradient Mold....29

10 Environmental Scanning Electron Micrographs of $106-$ AN Pilot-Scale Grout Core Samples Obtained 12-in. from the Edge of the Gradient

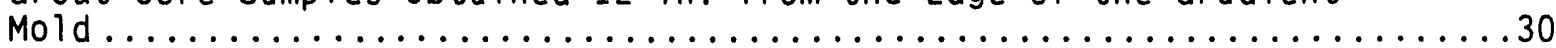

11 Environmental Scanning Electron Micrographs of 106-AN Pilot-Scale Grout Core Samples Obtained from the Centerline of the Gradient Mold....31

12 Environmental Scanning Electron Micrographs of 106-AN Pilot-Scale Grout Core Samples Obtained Approximately 6-in. from the Top of the Lift Mold. 


\section{IABLES}

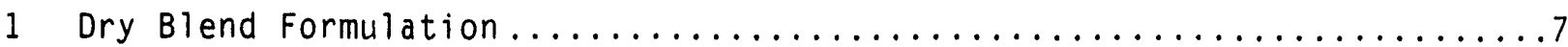

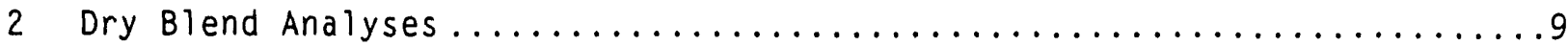

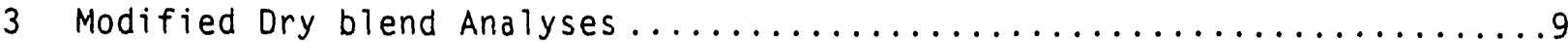

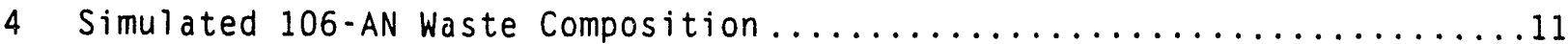

5 Leach Intervals Used for the ANS 16.1 Leach Test....................

6 Bulk Density. Compressive Strength and Sonic Velocity Results for Pilot-Scale Grout Specimens from the Lift Mold and Gradient Mold.......19

7 Comparison of Compressive Strength Summary Statistics for Pilot-Scale and Laboratory-Prepared 106-AN Grout Samples ......................23

8 Comparison of Bulk Density Summary Statistics for Pilot-Scale and Laboratory-Prepared 106-AN Grout Samples........................24

9 Bulk Density and Nitrate and Nitrite Leachability Indices for PilotScale Grout Specimens from the Lift Mold and Gradient Mold............25

10 Comparison of Nitrite Leachability Index Summary Statistics for Pilot-Scale and Laboratory-Prepared 106-AN Grout Samples ...............27

11 Comparison of Nitrate Leachability Index Summary Statistics for Pilot-Scale and Laboratory-Prepared 106-AN Grout Samples ..............28 


\section{INTRODUCTION}

The Grout Treatment Facility (GTF) at Hanford. Washington, will process the low-level fraction of selected double-shell tank (DST) wastes into a cementitious waste form. This facility, operated by Westinghouse Hanford Company (WHC), includes the Dry Materials Facility (DMF), the Grout Processing Facility (GPF), and the grout disposal vaults. The DMF receives, stores, and blends the individual dry materials for use in the grouting operation. Semitrailer trucks transport the dry materials to the GPF where these materials are mixed with the low-level waste in a continuous process at rates up to 70 gallons of grout per minute. The grout slurry is pumped into near-surface concrete vaults where it hardens and immobilizes the hazardous and radioactive constituents through chemical reactions and/or microencapsulation.

Pacific Northwest Laboratory (PNL) has a pilot-scale grout processing facility capable of grout outputs of up to $25 \%$ of the GPF. In 1986. the first major pilot-scale test demonstrated the effectiveness of the proposed grouting equipment and showed that grouting was an effective technique for immobilizing a simulated phosphate/sulfate waste (PSW). The grout dry-blend formulation used in this first test was a mixture ci 41 wt\% type I/II Portland cement, 40 wt\% Class F fly ash. 11 wt\% attapulgite-150 drilling clay, and 8 wt\% Indian Red Pottery Clay (Fow et al. 1987). Based on this pilot-scale test, a successful production campaign that solidified over 1 million gallons of PSW waste was conducted during 1988-1989 (Cline et al. 1992).

In 1988. PNL conducted a second major pilot-scale test to demonstrate the processing of a simulated double-shell slurry feed (DSSF) waste and to provide information for scale-up.(a) The dry blend for this test was a mixture of 47 wt\% Class F fly ash. 47 wt\% blast furnace slag, and 6 wt\% type I/II Portland cement. Information obtained during the second test led to concerns about the amount of heat generated during curing and the ultimate temperature of the grout. The results indicated that the temperature of the grout climbed well above the allowed $90^{\circ} \mathrm{C}$ maximum and degradation of the grout properties was possible. 
Westinghouse Hanford Company. PNL, and Oák Ridge National Laboratory (ORNL) collaborated to investigate approaches to reduce the grout temperatures. The first approach was to formulate a grout mixture that generated less heat and resulted in a lower ultimate temperature while meeting all other formulation criteria. These studies focused on the waste from tank 106-AN because this waste would be the major feed source for the next campaign. However, formulation studies conducted by ORNL and PNL determined that it was not possible through formulation adjustments alone to produce a grout that remains below acceptable temperatures while maintaining all other minimum product criteria.(a) Therefore, increased convective/evaporative cooling will be necessary to prevent excessive temperatures in the grout vault. A formulation that maximized the grout leachability index was chosen for the pilot-scale tests. This formulation included a dry blend consisting of $66 \mathrm{wt} \%$ class F fly ash. $20 \mathrm{wt} \%$ type I/II Portland cement, and 14 wt\% attapulgite clay. A second dry blend, consisting of 11 wt\% attapulgite clay. 20.7 wt\% type II Portland cement, and 68.3 wt\% class F fly ash. was also examined. Results of the pilot-scale test are presented by Bagasen (1993).

This report describes the tests conducted to determine compressive strength. bulk density, sonic velocity. leach resistance, and corrosivity of core samples obtained from the two pilot-scale molds.

\section{QBJECTIVES}

The primary objectives of the pilot-scale product characterization tests are listed below:

1. Determine the compressive strength, leachability, corrosivity, and density for core samples taken from large-scale pours and compare to laboratory-prepared specimens.

2. Determine the effects of different curing conditions (e.g. time at temperature) on the final grout properties.

3. Determine if grout properties near a lift interface are significantly different from grout properties away from an interface. 
The composition of the simulated 106-AN tank waste was based on the latest analyses available from WHC.(a) The required 3500 gallons of simulated waste was mixed in an insulated 4000-gal tank and heated to approximately $45^{\circ} \mathrm{C}$ before processing. The DMF mixed the required dry blend and production dryblend trucks transported the dry blend to PNL.

The pilot-scale tests were conducted using the grouting facilities located at PNL. The grout production rate was approximately 10 gallons per minute (gpm). A 5-in. Teledyne Readco twin-shaft continuous processor was used for mixing. This mixer is the same brand and type of mixer used in the GPF. The grout slurry fell into an agitated. conical surge tank that fed a Roper twostage progressing cavity pump. From the pump, the grout passed through 100 to $135 \mathrm{ft}$ of $3 / 4-i n$. schedule 40 carbon steel pipe into one of two molds.

The first mold was $8-\mathrm{ft}$ in diameter by $7.5-\mathrm{ft}$ high with plate coils on its outer surface. Water at a temperature of approximately $38^{\circ} \mathrm{C}$ was circulated through the plate coils to create a thermal gradient in the grout. Therefore. this mold will be referred to as the gradient mold. Thermocouples were used to measure the actual curing temperatures at various locations in the mold. As a result of the gradient, grout in the center of the mold cured at temperatures significantly higher than grout at the walls of the mold. After collecting the thermal data, core samples were obtained from three different locations in the mold to determine the effects of curing conditions on grout properties.

The second mold was 3-ft wide by $7.5-\mathrm{ft}$ long $X 10-\mathrm{ft}$ deep and was used to study the effects of pouring in lifts and convective/evaporative cooling. This mold will be referred to as the lift mold. The length and width of the lift mold were scaled to match the length/width ratio on the production vault. The lift mold was insulated to reduce heat losses through the walls and was instrumented with thermocouples and filled in four $2-\mathrm{ft}$ lifts. The lifts were poured with one week between each lift. The temperature and heat removal information obtained from the lift mold was used to determine the effects of 
pouring in lifts. After the thermal information was collected and after curing for a minimum of $28 \mathrm{~d}$, two core samples were taken to determine if grout properties at a lift interface were significantly different from properties away from an interface. 


\section{EACILITY DESCRIPTION}

A schematic of the pilot-scale system is shown in Figure 1.

\section{SIMULATED WASTE FEED SYSTEM}

The simulated 106-AN waste was mixed and stored in an insulated 4000-gal stainless steel tank. The tank was equipped with a 10-HP, variable-speed agitator and a circulation heater for temperature control. Centrifugal pumps located below the tank and downstream from the first pump were used to transfer the waste through a 1 -in. carbon steel pipe to the grout mixer.

\section{DRY BLEND FEED}

The required dry-blend materials were blended at the DMF, transported by trailers. and transferred from access ports in the top of the trailers through a suction wand to a storage bin. The storage bin is positioned above the active bin and automatically fills the active bin on a signal from the feeder controller.

\section{GROUT MIXER}

The grout mixer is a Teledyne Readco 5-in. Twin-Shaft Continuous Mixer. The mixer speed for the pilot-scale run was 250 RPM, which was based on matching the paddle tip speed in the production mixer. Predetermined quantities of dry blend and simulated waste were metered to the mixer to obtain the desired grout production rate. The mixed grout slurry discharged into a 17.5 -gal agitated conical surge tank.

\section{GROUT PUMP AND PIPING}

The grout slurry was pumped through $3 / 4-i n$. schedule 40 carbon steel pipe using a Roper progressing cavity pump with an ethylene-propylene-diene-monomer (EPDM) stator. The total length of pipe when plumbed to the lift mold was $119.25 \mathrm{ft}$ and when plumbed to the gradient mold was $135.5 \mathrm{ft}$. 


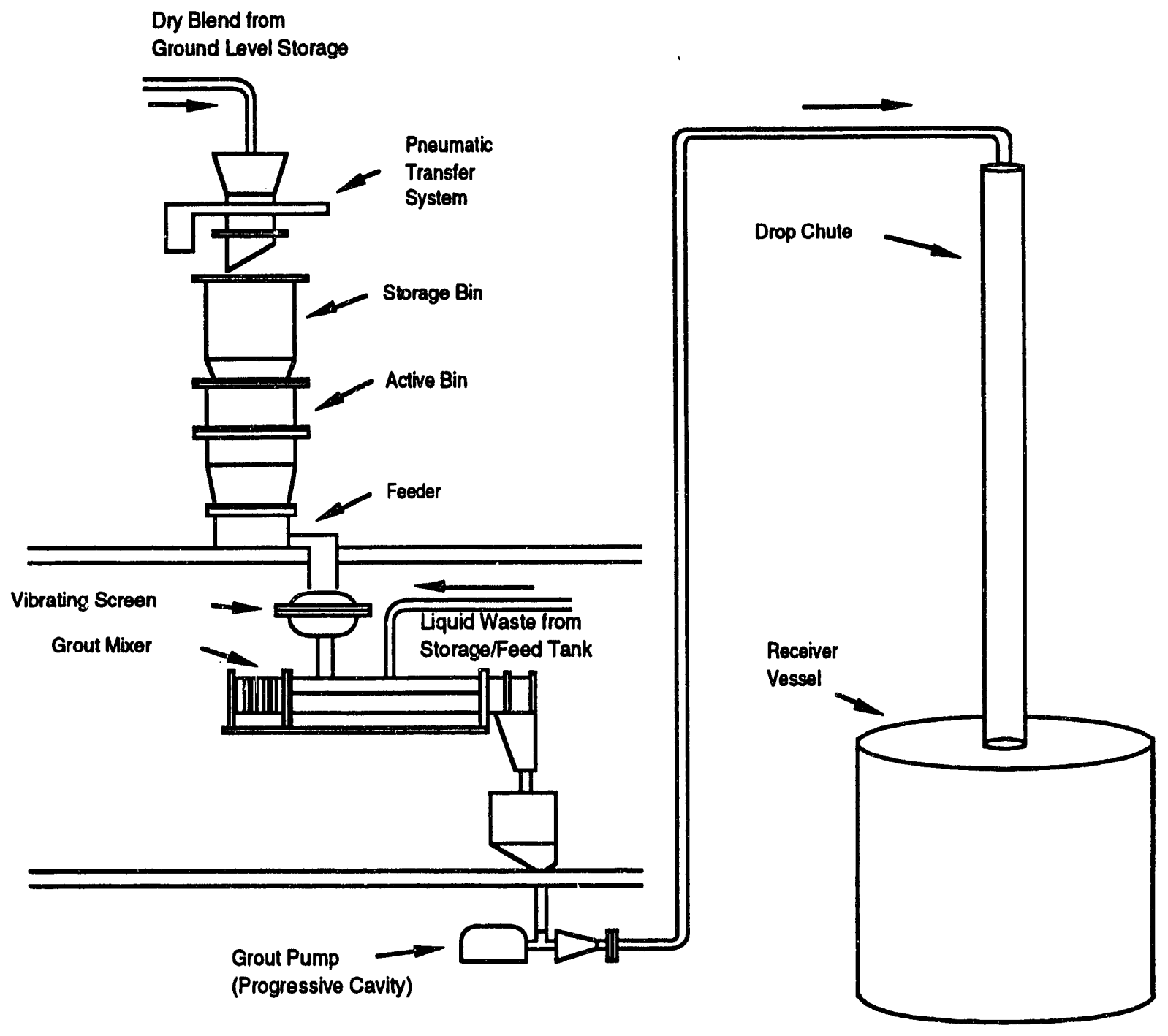

FIGURE 1. Schematic of the Pilot-Scale Grout System 


\section{GRADIENT MOLD}

The gradient mold was constructed from an 8-ft-dia $\times 7.5-\mathrm{ft}$-high carbon steel tank. This tank was placed on a structural support and its circumference was surrounded by platecoils. The top and bottom were insulated to minimize the heat loss through those surfaces. Water was continuously circulated through the plate coils at a nominal temperature of $38^{\circ} \mathrm{C}$. The gradient mold was equipped with a 1-ft-dia. 27.5-ft-long polyvinyl chloride (PVC) pipe through which the grout fell $235 \mathrm{ft}$ after discharging from the grout pipe, simulating the maximlim drop that the grout will see in the fullscale vault.

The gradient mold had 40 type-T thermocouples to measure the temperature profiles and determine the maximum temperature achieved in the grout.

\section{LIFT MOLD}

The lift mold was constructed of reinforced plywood and had the approximate inner dimensions of $3-\mathrm{ft}$ wide $\times 7.5 \mathrm{ft}$ long $\times 10-\mathrm{ft}$ tall. The box had a 20-mil high-density polyethylene liner to contain the grout slurry and 4 in. of foam insulation to reduce heat losses through the sides and top of the box. Two inches of duraboard insulation were placed on the bottom of the mold under the 20-mil liner.

\section{DRY BLEND}

The two dry-blend formulations used in the pilot-scale grout runs are shown in Table 1. The type I/II Portland cement was obtained from Ash Grove

IABLE 1. Dry Blend Formulation

$\begin{array}{cccc}\text { Component } & \frac{c}{\text { Baseline }} \begin{array}{c}\text { Formulation, wt\% } \\ \text { Class F Fly Ash }\end{array} & 66.0 & \begin{array}{c}\text { Adjusted } \\ \text { Formulation, wt\% }\end{array} \\ \text { Type I/I I Portland Cement } & 20.0 & 68.3 \\ \text { Attapulgite Clay } & 14.0 & 20.7\end{array}$


Cement in Spokane. Washington: the Class $F$ fly ash was obtained from Pozzolanic Northwest in Mercer Island. Washington: and the attapulgite clay was purchased from Floridin Company in Quincy. Florida. A 5-1b sample of each dry-blend ingredient was sent to the WHC Analytical Laboratories. These samples were used to determine the baseline data for the Fourier Transform Infrared (FTIR) spectrometry technique that was used to confirm the proper quantity of each component in the blended material.

The DMF was used to mix the dry-blend material required for the pilotscale tests. Use of the DMF facility was important because the dry-blend mixing method has been shown to be an important consideration when attapulgite clay is one of the dry-blend components (Lokken et a l. 1987). The dry blend for the main portion of the pilot-scale grout run was blended in eight 5.000 lb batches. A slightly modified dry-blend formulation that had less clay was used for the fourth lift. This dry blend was produced in two 4.000-1b batches.

A 5-1b sample from each batch of blended material was sent to WHC Analytical Laboratories for FTIR spectrometry to determine the amount of each component. The results of these analyses for the first eight batches are shown in Table 2. All eight batches blended for the main portion of the production scale run were within the \pm 5 relative wt\% tolerance.

The analyses of the samples of the modified formulation are shown in Table 3. The analysis shows that the cement content was slightly below the allowable \pm 5 relative wt\% tolerance. However, the seals on the samples sent to the WHC analytical laboratories had been broken and the integrity of these samples was suspect. Therefore, an additional sample of material was taken from a sealed container intended for other studies. Analysis of this sample indicated that all materials fell within the \pm 5 relative wt\% tolerance. Even if the cement was slightly low. this dry-blend composition was adequate to determine if the modification to the dry-blend formulation would produce the desired results. 
The reference to 106-AN waste refers to the waste in Tank 241-AN-106. However, before the waste in Tank 241-AN-106 is grouted, it will be transferred to an agitated feed tank (102-AP) which already contains the heel of a waste from an earlier PSW grout campaign. Therefore, the pilot-scale test attempted to simulate this combined waste. A total of 3500 gallons of simulated waste were required to complete the pilot-scale test.

IABLE2. Dry Blend Analyses

\begin{tabular}{|c|c|c|c|}
\hline Batch \# & Attapulaite Clay & Portland cement & Class F fly ash \\
\hline Target Value $=$ & $14.0 \pm 0.7$ & $20.0 \pm 1.0$ & $66.0 \pm 3.3$ \\
\hline 1 & 14.27 & 19.93 & 66.21 \\
\hline 2 & 13.95 & 20.25 & 65.23 \\
\hline 3 & 14.18 & 19.77 & 63.78 \\
\hline 4 & 13.87 & 19.66 & 63.21 \\
\hline 5 & 13.93 & 19.86 & 68.44 \\
\hline 6 & 14.14 & 20.03 & 66.36 \\
\hline 7 & 13.99 & 19.88 & 68.00 \\
\hline 8 & 13.80 & 20.49 & 68.03 \\
\hline
\end{tabular}

IABLE 3. Modified Dry Blend Analyses

Batch 非

Target value $=$ 1 (a)

$2(a)$

Sealed Sample
Attapulgite Clay

$$
11.0 \pm 0.55
$$

10.54

10.47

10.87
Portland Cement

$$
20.7 \pm 1.04
$$

19.44

19.42

20.49
Class F fly ash

$$
\begin{gathered}
68.3 \pm 3.42 \\
70.37 \\
70.02 \\
70.11
\end{gathered}
$$

(a) Seals on samples sent to the laboratory had been broken. 
The pilot-scale run used the best available estimate of the composition in the feed tank after combining the wastes.(a). The target composition and final analysis of the simulated waste are shown in Table 4 . The total organic carbon was analyzed using a Xertex-Dohrmann Model DC-80 TOC analyzer. The solution was analyzed for anions using a Dionex Series $4000 i$, ion chromatograph (IC) and for cations using a Jarrel-Ash Model 975 Plasma Atomcomp inductively coupled plasma spectrometer (ICP). The analyzed values for the main constituents agreed fairly well with the target values. The concentration of some of the minor constituents such as boron, calcium. silicon, and magnesium were higher than the target value.

(a) Hendrickson D.W. and T. L. Welsh. 1992. Hanford Grout Disposal Program Champaign 102 Sampling and Characterization Plan. WHC-SD-WM-TP-136 (Draft). Westinghouse Hanford Company, Richland, Washington. 
IABLE 4. Simulated 106-AN Waste Composition

\begin{tabular}{lll} 
Species & $\begin{array}{l}\text { Analysis } \\
\text { Moles/Liter }\end{array}$ & $\begin{array}{l}\text { Target } \\
\text { Moles/Liter }\end{array}$ \\
\hline $\mathrm{Al}$ & 0.383 & 0.341 \\
$\mathrm{~B}$ & 0.016 & 0.0026 \\
$\mathrm{Ca}$ & 0.004 & 0.00186 \\
$\mathrm{Na}$ & 3.43 & 3.954 \\
$\mathrm{Ni}$ & 0.0011 & 0.00104 \\
$\mathrm{Si}$ & 0.008 & 0.00158 \\
$\mathrm{P}$ & 0.211 & 0.196 \\
$\mathrm{~K}$ & $\mathrm{Not}$ Analyzed & 0.246 \\
$\mathrm{Mg}$ & 0.0010 & 0.000107 \\
$\mathrm{Cl}$ & 0.093 & 0.0675 \\
$\mathrm{NO} 2$ & 0.536 & 0.534 \\
$\mathrm{NO} 3$ & 1.279 & 1.130 \\
$\mathrm{SO} 4$ & 0.029 & 0.0273 \\
$\mathrm{PO} 4$ & 0.173 & 0.196 \\
$\mathrm{TOC}$ & 0.248 & $0.238(\mathrm{a})$ \\
$\mathrm{CO} 3$ & 0.359 & $0.341(\mathrm{~b})$ \\
$\mathrm{Hal}$ & &
\end{tabular}

(a) Calculated from EDTA, HEDTA, Glycolate, and Citrate Additions (b) Calculated from Total Carbon and TOC Values 


\section{PROCEDURES}

\section{CORE DRILLING AND SAMPLE PREPARATION}

Five cores were obtained from the pilot-scale molds after one to two months of curing. Three cores were taken from the gradient mold at $3 \mathrm{in}$. and $12 \mathrm{in.}$ from the edge, and from the center of the mold. Two cores were drilled vertically, $12 \mathrm{in}$. on each side of the center of the lift mold. Coring was conducted using a 1.875-in. inner diameter diamond core bit. No water was used during coring. The cores were placed into double plastic bags, sealed. and stored for approximately six and one half months at ambient temperature until tested.

Before testing, the cores were turned on a lathe to a diameter of 1.5 in. and cut to a length of $3.0 \mathrm{in}$.

\section{COMPRESSIVE STRENGTH}

Compressive strength testing was conducted with an Instron test machine at a constant cross-head speed of $0.05 \mathrm{in.} / \mathrm{min}$. The load-to-failure was determined from the maximum point of a load-deformation curve. Compressive strength values were calculated by dividing the maximum load by the average cross-sectional surface area of the cylinders. The length-to-diameter ratio of these samples was two.

\section{SONIC VELOCITY}

Sonic velocity was determined using a James Sonic Velocity Meter (V-Meter) Model 4902, according to the test method outlined in ASTM C597-83 (ASTM 1985). Water was used as an acoustical couplant to transmit the sonic pulse thrcugh the sample. Ends of the sample were wetted by briefly immersing 0.5 to $1 \mathrm{~cm}$ of the flat face in deionized (DI) water. The transducers were also kept wet and clean by immersing them in DI water between measurements. The transducers were pressed firmly onto the ends of the sample. Firm pressure was applied and the minimum transit time, in microseconds, indicated by the instrument was recorded. 
AMERICAN NUCLEAR SOCIETY (ANS 16,1) LEACH TEST

The ANS 16.1 leach test (ANS 1986) was conducted on seven core samples from the lift mold (three from near the interfaces of the lifts and four from the near the center of each $1 \mathrm{ift}$ ) and nine from the gradient mold. This test is an intermittent leachate exchange test designed to simulate a dynamic leaching situation. The leachate exchange intervals used in these tests are shown in Table 5 .

The samples used in these tests were right circular cylinders with approximate dimensions of $3.8 \mathrm{~cm}$ dia. by $7.6-\mathrm{cm}$ high. The samples, which had surface areas of approximately $114 \mathrm{~cm}^{2}$. were suspended by nylon monofilament in approximately $1140 \mathrm{~mL}$ of deionized water within plastic containers. After the elapsed time periods, the samples were removed from the leachates and placed into containers containing fresh leachant. The $\mathrm{pH}$ of the leachates was measured after removing the samples and filtered aliquots of leachate were submitied for $\mathrm{NO}_{3}$ and $\mathrm{NO}_{2}$ analysis by ion chromatography (IC).

The ANS 16.1 leach test is designed to determine a "figure of merit" parameter called the leachability index ( $L$ ). The leachability index for a given species is defined as the negative logarithm (base 10 ) of the effective diffusion coefficient (D) of that species. The effective diffusivity is given by (ANS 1986)

IABLE 5. Leach Intervals Used for the ANS 16.1 Leach Test

\begin{tabular}{|c|c|c|}
\hline $\begin{array}{c}\text { Leach } \\
\text { Interval } \\
\text { No. }\end{array}$ & $\begin{array}{c}\text { Time } \\
\text { Between } \\
\text { Intervals }\end{array}$ & $\begin{array}{c}\text { Cumulative } \\
\text { Time }\end{array}$ \\
\hline 1 & $7 \mathrm{~h}$ & $7 \mathrm{~h}$ \\
\hline 2 & $17 \mathrm{~h}$ & $1 d$ \\
\hline 3 & $24 \mathrm{~h}$ & $2 d$ \\
\hline 4 & $48 \mathrm{~h}$ & $4 d$ \\
\hline 5 & $72 \mathrm{~h}$ & $7 d$ \\
\hline
\end{tabular}




$$
D=\pi\left[\frac{\left(a_{n} / A_{0}\right)}{(\Delta t)_{n}}\right]^{2}\left[\frac{v}{S}\right]^{2} T
$$

where, $D=$ effective diffusivity, $\mathrm{cm}^{2} / \mathrm{s}$

$a_{n}=$ concentration of ion released from the specimen during the leaching interval $n$

$A_{0}=$ total amount of species in the specimen at the beginning of the each test

$(\Delta t)_{n}=t_{n}-t_{n-1}$. duration of the $n$-th leaching interval, s

$V=$ volume of specimen, $\mathrm{cm}^{3}$

$S=$ geometric surface area of specimen, $\mathrm{cm}^{2}$

$T=\left[1 / 2\left(\sqrt{t_{n}}+\sqrt{t_{n-1}}\right)\right]^{2}$, representing the "mean time" of the leaching interval. s.

When greater than $20 \%$ of the total inventory of a species is leached, the effective diffusivity is calculated by

$$
D=\frac{G d^{2}}{t}
$$

where, $D=$ effective diffusivity, $\mathrm{cm}^{2} / \mathrm{s}$

$G=$ dimensionless time factor for cylinder

$d=c y l i n d e r$ diameter, $c m$

$t=$ elapsed leaching time from beginning of test. $s$.

The treatment of the data from this type of leach test assumes that the release of ions from the waste form is controlled by diffusion. For pure diffusional release, the cumulative amount of species released from the sample plotted as a function of the square root of time would yield a straight line passing through the origin at time zero. 


\section{CORROSIVITY}

The corrosivity of three reference 106-AN grout samples was determined using the WDOE Method 83-13 (WDOE 1984). Approximately $50 \mathrm{~g}$ of grout were combined with an equai weight of distilled water and agitated on a shaker table for $30 \mathrm{~min}$. The $\mathrm{pH}$ of the solution was then measured. The three $\mathrm{pH}$ values were then logarithmically averaged, i.e.. the antilogs of the pH readings were averaged and the $\log$ of the result was calculated. According to this procedure, a solid is considered corrosive if the average pH of the solutions is less than or equal to 2. or greater than or equal to 12.5 .

\section{SCANNING ELECTRON MICROSCOPY}

Scanning electron microscopy was conducted on specimens of 106-AN pilotscale grout using an Environmental Scanning Electron Microscope (ESEM) from Electroscan, Danvers. Massachusetts. The specimens were examined at an accelerating voltage of $20 \mathrm{kV}$ and at pressures from 5.6 to 5.9 torr. 


\section{RESULTS}

This section discusses the results of compressive strength tests, bulk density. sonic velocity. ANS 16.1 leachability, and WDOE corrosivity tests. The results of some tests on pilot-scale grout samples are compared with results on laboratory produced samples.

\section{COMPRESSIVE GIRENGTH. BULK DENSITY. AND SONIC VELOCITY}

Compressive strength measurements were conducted on seven core samples from the lift mold (trree from near the interfaces of the lifts, and four from the near the ceriter of each i ift) and nine from the gradient mold. The samples from the gradient mold were taken from $3 \mathrm{in}$. and $12 \mathrm{in}$. from the edge. and from near the center of the mold. Three specimens were obtained from near the middle of the cores from each location for testing. The results of the compressive strength and sonic velocity tests and bulk densities are listed in Table 6.

Figure 2 shows the compressive strength of the 106-AN grout samples in relation to their position within the lift mold. There is no clear trend evidenced in the figure, i.e., there does not appear to be an effect of position within the mold on the strengths. All strengths were greater than the desired 500 psi. as suggested by Riebling and Fadeff (1991).

Samples from the gradient mold were tested to determine whether the initially high curing temperatures affected grout properties. Figure 3 illustrates the approximate temperature/time profiles for three positions within the mold. These positions are the closest to those where the three cores were obtained. The maximum temperatures attained at these locations were approximately $85^{\circ} \mathrm{C}, 74^{\circ} \mathrm{C}$, and $55^{\circ} \mathrm{C}$, respectively. After about $1000 \mathrm{~h}$, the temperatures at all three locations were the same. After coring, the samples were stored in sealed plastic bags under ambient conditions until tested. Figure 4 shows the average compressive strengths of samples from the three cores. Each data point is the average of three measurements; the error bars represent one 
standard deviation. The highest strengths were observed for the samples from along the centerline of the mold. where the maximum temperature was about $85^{\circ} \mathrm{C}$. The lowest strengths were from the core taken $12 \mathrm{in}$. from the wall of the mold. The maximum temperature at this point was about $74^{\circ} \mathrm{C}$. The same general trend was seen in laboratory-produced grouts cured at $55^{\circ} \mathrm{C}, 70^{\circ} \mathrm{C}$, and $85^{\circ} \mathrm{C}$. i.e.. the samples cured at $70^{\circ} \mathrm{C}$ exhibited lower average strengths than those cured at either $55^{\circ} \mathrm{C}$ or $85^{\circ} \mathrm{C}, 1285$ psi vs. 1598 psi and 1504 psi, respectively (Lokken et a1. 1993). 
IABLE 6. Bulk Density. Compressive Strength, and Sonic Velocity Results for Pilot-Scale Grout Specimens from the Lift Mold and Gradient Mold

\begin{tabular}{|c|c|c|c|c|}
\hline Specimen & Location & $\begin{array}{c}\text { Density. } \\
\mathrm{g} / \mathrm{cm}^{3}\end{array}$ & $\begin{array}{c}\text { Strength. } \\
\text { psi }\end{array}$ & $\begin{array}{c}\text { Velocity } \\
\mathrm{m} / \mathrm{s}\end{array}$ \\
\hline Lift Mold & Interface $(3-4)$ & 1.528 & 782 & 2149 \\
\hline Lift Mold & Interface $(2-3)$ & 1.545 & 1000 & 2248 \\
\hline Lift Mold & Interface $(1-2)$ & 1.535 & 1145 & 2228 \\
\hline Lift Mold & Center ( Lift 4) & 1.541 & 888 & 2130 \\
\hline Lift Mold & Center ( Lift 3) & 1.505 & 1438 & 2263 \\
\hline Lift Mold & Center (Lift 2) & 1.502 & 989 & 2113 \\
\hline Lift Mold & Center (Lift 1) & 1.501 & 602 & 2095 \\
\hline Gradient Mold & 3-in. from edge & 1.492 & 819 & 2117 \\
\hline Gradient Mold & 3-in. from edge & 1.483 & 813 & 2100 \\
\hline Gradient Mold & 3-in. from edge & 1.499 & 894 & 2141 \\
\hline Gradient Mold & 12-in. from edge & 1.488 & 770 & 2101 \\
\hline Gradient Mold & 12-in. from edge & 1.471 & 636 & 2013 \\
\hline Gradient Mold & 12-in. from edge & 1.505 & 732 & 2107 \\
\hline Gradient Mold & 48-in. from edge & 1.504 & 1039 & 2192 \\
\hline Gradient Mold & 48-in. from edge & 1.513 & 909 & 2156 \\
\hline Gradient Mold & 48-in. from edge & 1.505 & 924 & 2130 \\
\hline
\end{tabular}




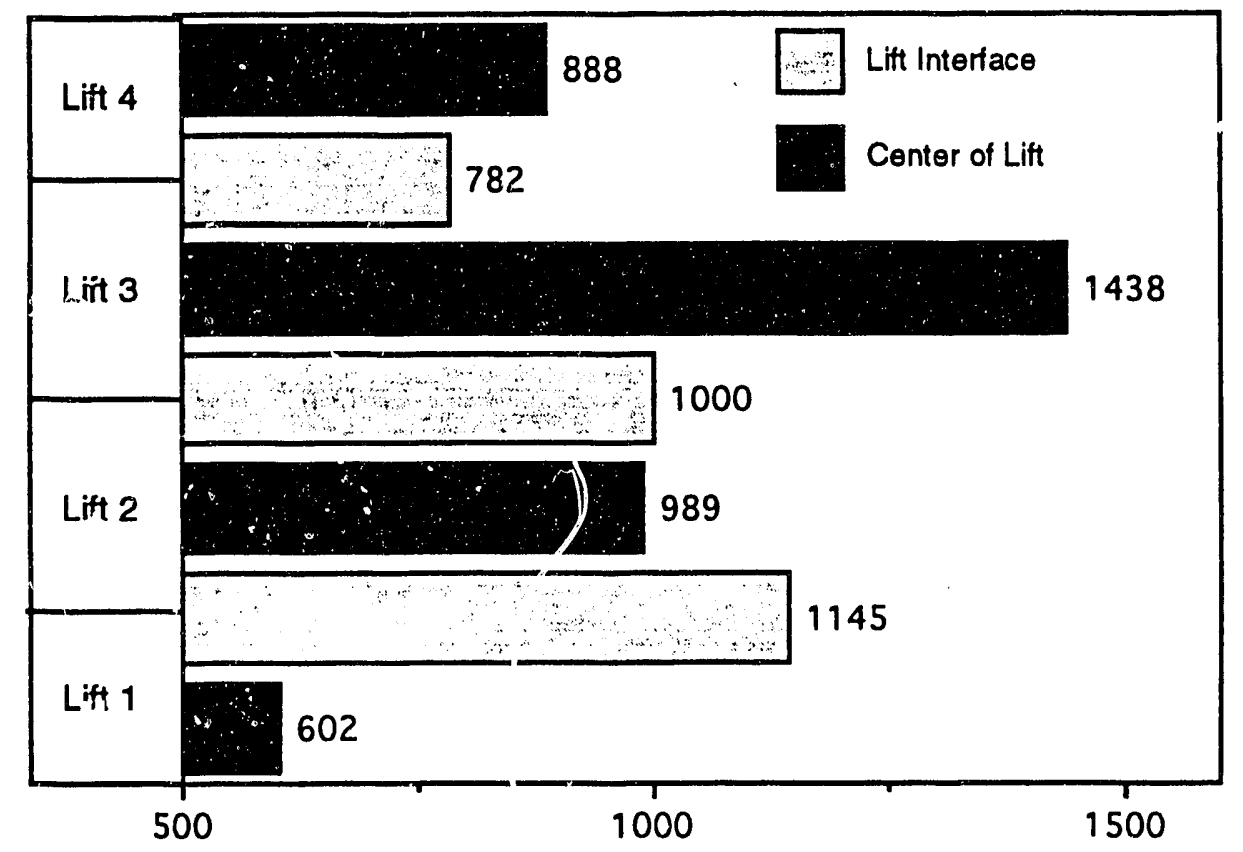

EIGURE 2. Compressive Strength of 106-AN Grout Samples from the Lift Mold

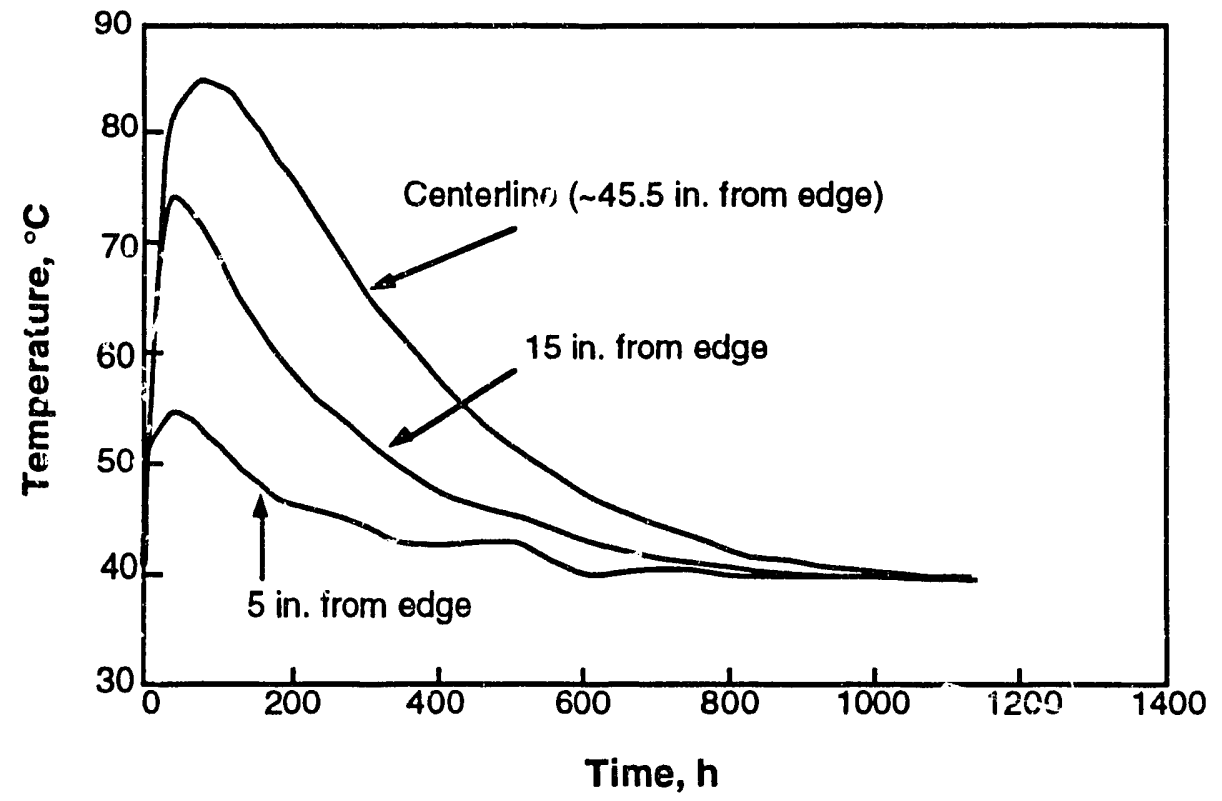

EIGURE 3. Approximate Average Temperatures for Pilot-Scale 106-AN Grout Cores from 36 to $60 \mathrm{in}$. Depth 


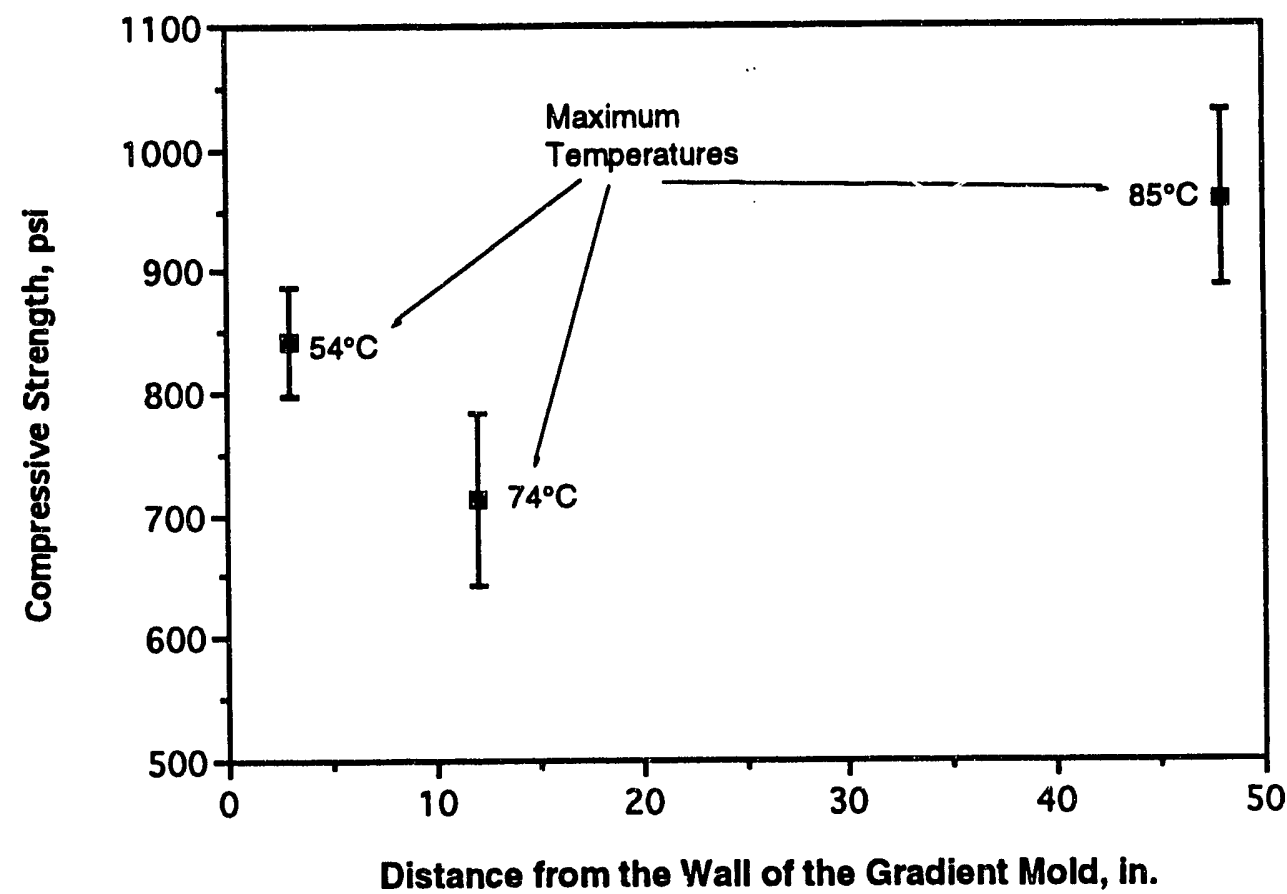

EIGURE 4. Average Compressive Strengths for 106-AN Grout Samples as a Function of Distance from the Gradient Mold Surface (Note: Temperatures are the average between 36 and $60 \mathrm{in}$. from the top surface.)

Sonic velocity measurements were conducted on the pilot-scale grout specimens before the compressive strength tests were conducted to determine whether a good correlation existed between the results of these two tests. Figure 5 illustrates the relationship between the sonic velocity and compressive strength. There appears to be a positive correlation between these two parameters; however, there is quite a bit of scatter in the data around the regression line. A similar plot showing the relationship between sonic velocity and bulk density is shown in figure 6 . The correlation between these two properties is not as good $\left(R^{2}=0.44\right)$ as between the compressive strength and sonic velocity $\left(R^{2}=0.72\right)$.

Tables 7 and 8 compare summary statistics for compressive strength and density, respectively, for the pilot-scale and laboratory-produced grout 


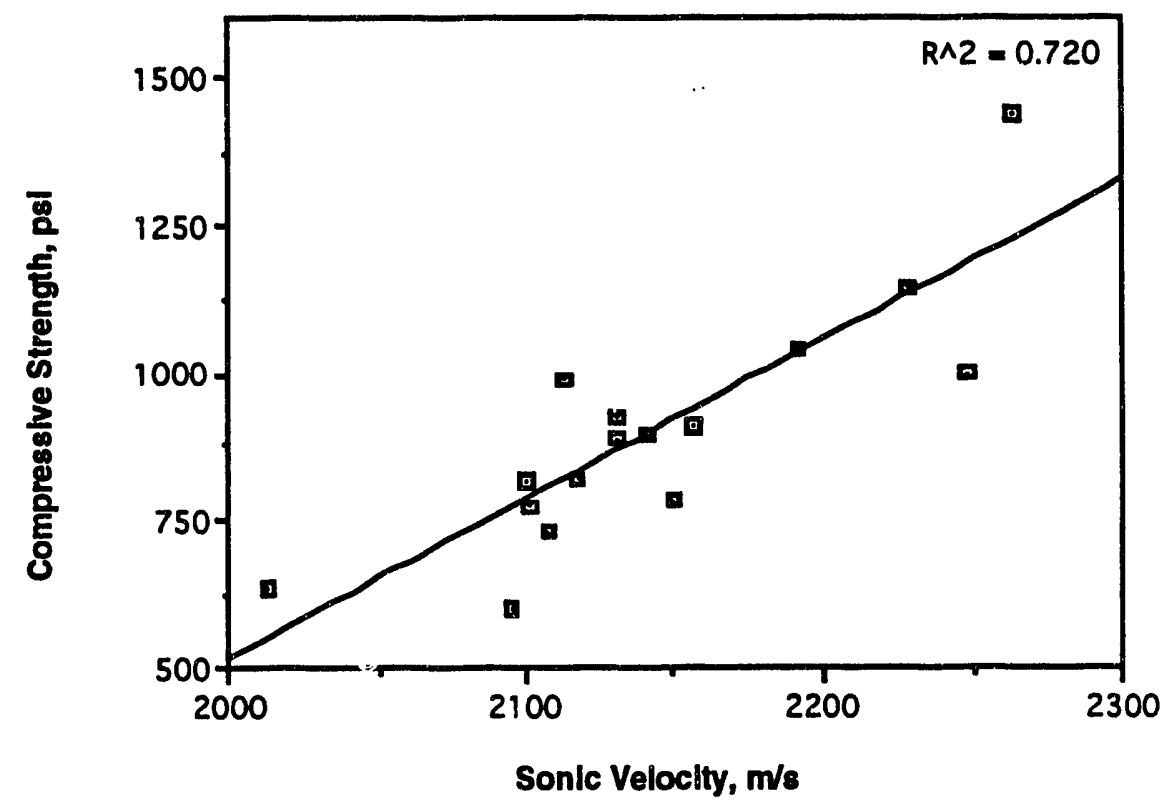

FIGURE 5. Correlation Between Sonic Velocity and Compressive Strength of 106-AN Grout Core Samples

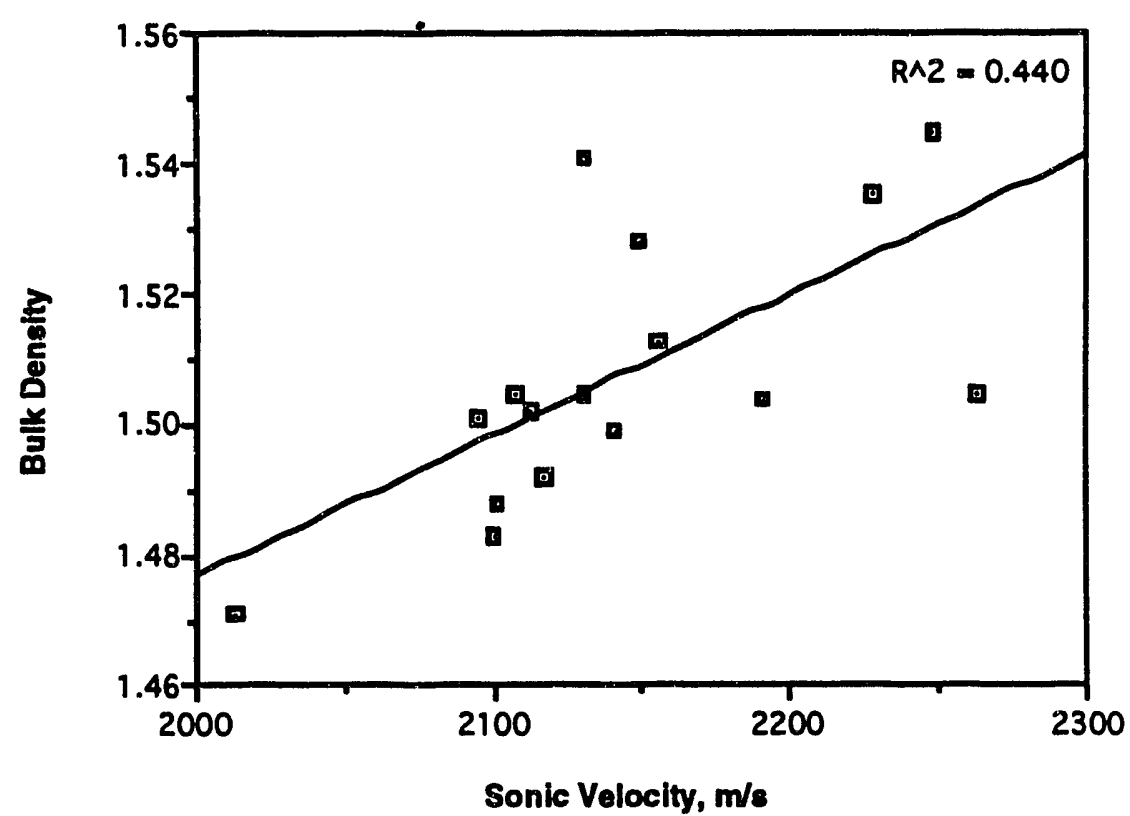

EIGURE 6. Correlation Between Sonic Velocity and Bulk Density of 106-AN Grout Core Samples 
samples. The laboratory samples were from the variability study (Lokken et a). 1993) and were cured at $65^{\circ} \mathrm{C}$ for 28 days: The average strengths of the pilot-scale samples were less than the samples produced in the laboratory ( 899 psi vs. 1235 psi). The lower strengths may be caused by the larger porosity of the pilot-scale samples. The density data shown in Table 8 corresponds to an increased porosity of aiout $3 \%$ in the pilot-scale samples.

One-way analysis of variance (ANOVA) tests were applied to the bulk density, compressive strength, and sonic velocity data obtained from samples from the gradient mold. This test was used to test the hypothes is that the means across the distances in the gradient mold are equal. The means are declared to be significantly different if the $p$-value for the ANOVA is less than 0.05 . Results indicate that there was a significant difference in the means across the distance for compressive strength. The bulk density and sonic velocity were not significantly different ( $p$-values were 0.087 and 0.080 , respectively).

IABLE 7. Comparison of Compressive Strength Summary Statistics for Pilot-Scale and Laboratory-Prepared 106-AN Grout Samples

\begin{tabular}{lcc} 
& \multicolumn{2}{c}{ Compressive Strength. psi(a) } \\
\cline { 2 - 3 } & $\begin{array}{c}\text { Laboratory } \\
\text { Prepared }\end{array}$ & $\frac{\text { Pilot-Scale }}{\text { Mean }}$ \\
\cline { 2 - 3 } Standard Deviation & 1235 & 899 \\
Minimum & 373 & 203 \\
Maximum & 712 & 602 \\
Range & 1992 & 1438 \\
N & 1280 & 836
\end{tabular}

(a) Laboratory samples were cured 28 d at $65^{\circ} \mathrm{C}$; pilot-scale samples were cured 1 to $2 \mathrm{~m}$ in molds and $6 \mathrm{~m}$ at room temperature 
IABLE 8. Comparison of Bulk Density Summary Statistics for Pilot-Scale and Laboratory-Prepared 106-AN Grout Samples

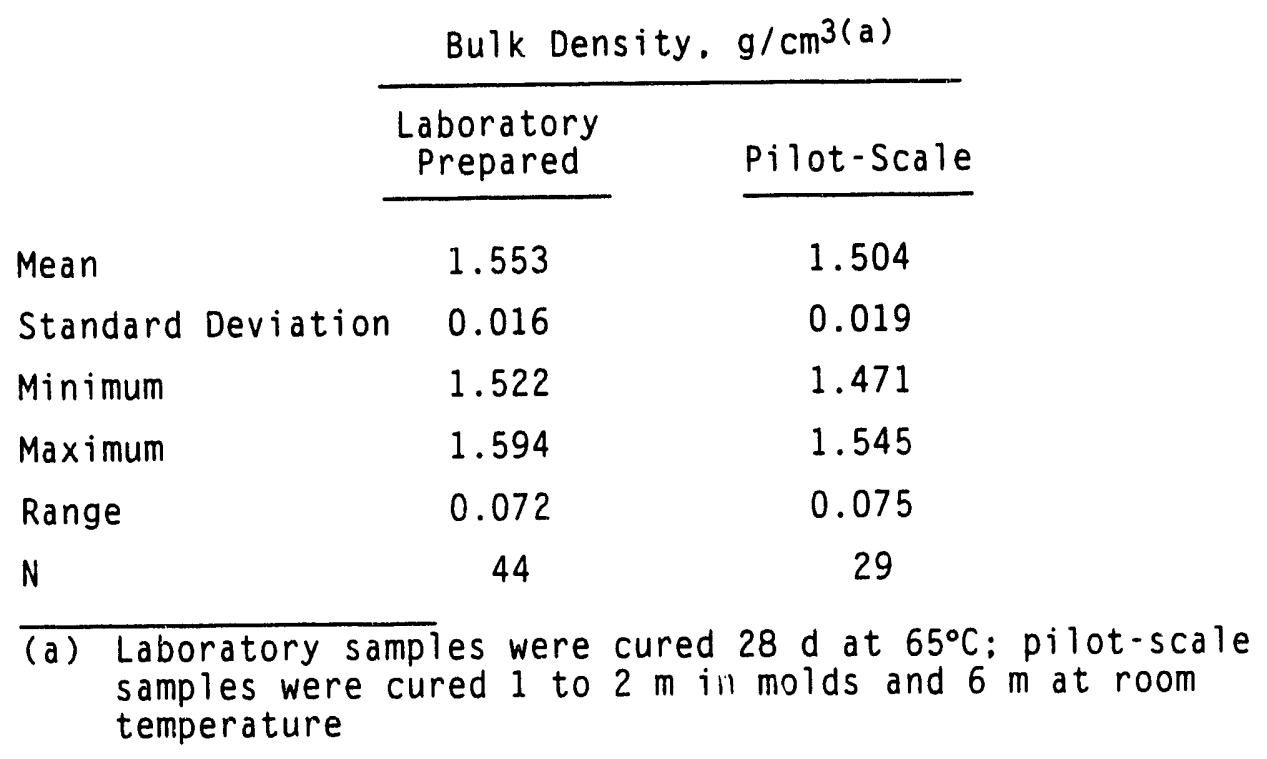

\section{ANS 16.1 LEACHABILITY}

Seven-day ANS 16.1 leach tests were conducted on seven core samples from the lift mold (three from near the interfaces of the lifts, and four from the near the center of each $l i f t$ ) and nine from the gradient mold. The samples from the gradient mold were taken from $3 \mathrm{in.}$ and $12 \mathrm{in.} \mathrm{from} \mathrm{the} \mathrm{edge.} \mathrm{and}$ from near the center of the mold. Three specimens were obtained from near the middle of the cores from each location for tesiing. The average nitrate and nitrite leachability indices for the various samples are listed in Table 9.

Figure 7 shows the nitrate leachability index for samples from the lift mold. Although it appears in the figure that the nitrate leachability index is lower for those samples near the interface of the lifts, only the sample at the interface between 1 ifts 1 and 2 exhibited a leach index that is significantly lower. It should be noted that the data in this figure represent single data points, i.e.. one sample per location. and most of the variation in values can be attributable to small variations in the original 
IABLE 9. Bulk Density and Nitrate and Nitrite Leachability Indices for Pilot-Scale Grout Specimens from the Lift Mold and Gradient Mold

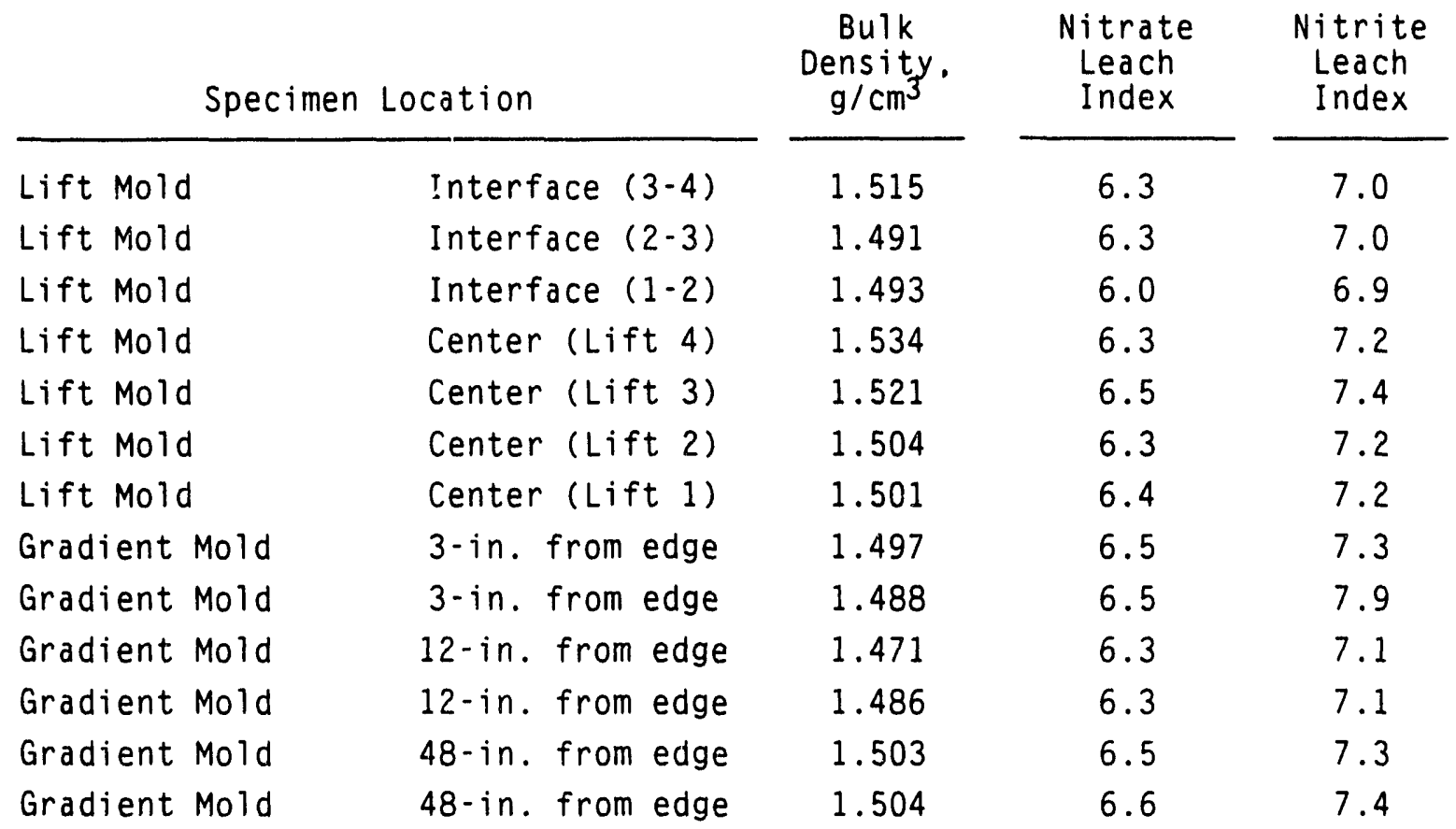

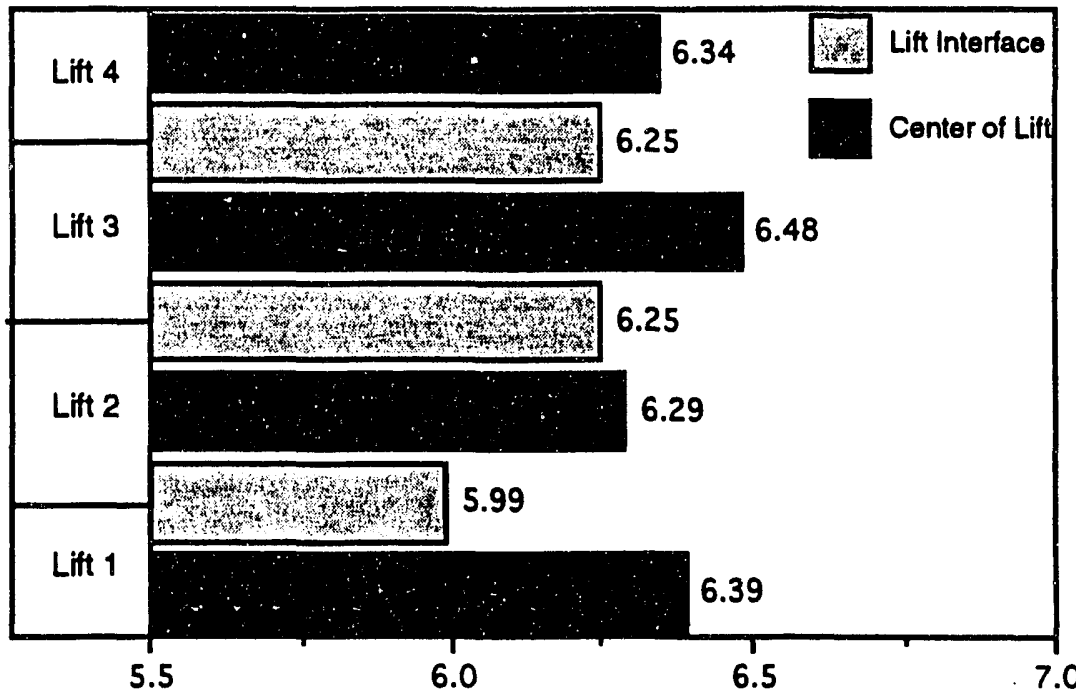

Nitrate Leachability Index

EIGURE 7. Nitrate Leachability Indices of 106-AN Grout Samples from the Lift Mold 
inventory in the samples. The calculations assumed that all samples had the same initial inventory. The grout formulation used in lift 4 was slightly different from those used in the other lifts. The attapulgite content was reduced to $11 \mathrm{wt} \%$ and the mix ratio was $8.4 \mathrm{lb} / \mathrm{gal}$. Despite the change in formulation, the leachability was not adversely affected.

Figure 8 shows the nitrate leachability indices from three cores from the gradient mold, plotted as a function of distance from tile mold surface. In a similar fashion to the compressive strengths, the samples taken $12 \mathrm{in.}$ from the wall had the lowest leachability indices. The highest leach indices were from samples taken along the centerline of the mold, where the peak temperature was about $85^{\circ} \mathrm{C}$. All the samples from the gradient mold had nitrate and nitrite leachability indices greater than the minimum requirement of 6 .

Tables 10 and 11 compare the summary statistics for nitrite and nitrate leachability indices, respectively, for samples produced in the laboratory with samples from the pilot-scale cores. The leachability indices from the laboratory-produced samples were consistently higher than those from the pilot-scale core samples. The lower leach indices for the pilot-scale cores are most likely due to an increase in total available surface area caused by the large surface pores. The increased porosity resulted from air entrainment in the grout slurry. The viscosity of the slurry entering the molds was considerably higher than the laboratory-produced grouts as a result of the shearthickening that occurred during pumping.

Analysis of variance tests were performed on the nitrite and nitrate leachability indices for samples from the gradient mold and from the lift mold. For the gradient mold samples, the hypothesis that the means across the distances are equal was tested. The results indicate that there were significant differences between the nitrate leach indices but not for the nitrite leach indices. The same approach was used to test the hypothesis that the mean of leachability index for samples near the center of the lifts in the lift mold was equal to the leachability index for samples from near the interface of the lifts. The results of these analyses indicate that there was a significant difference in the means for the nitrite leachability index. 


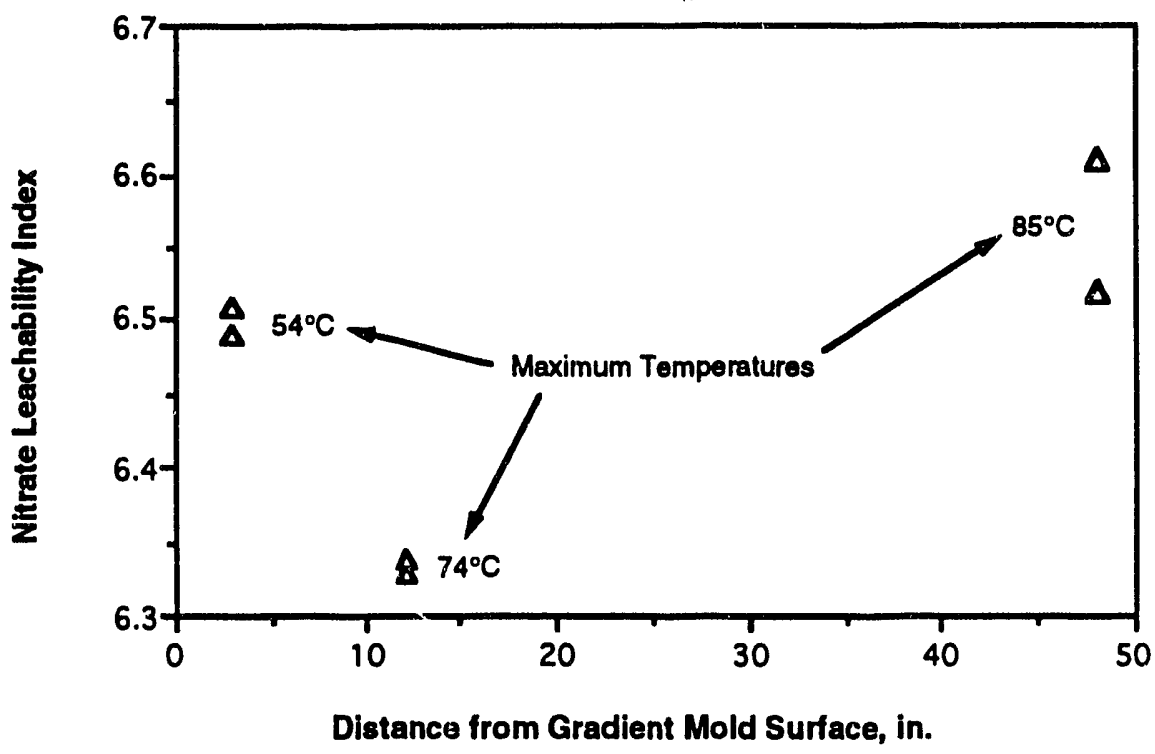

EIGURE 8. Nitrate Leachability Indices for 106-AN Grout Samples as a Function of Distance from the Gradient Mold Wall (Note: Temperatures are the average maximum attained between 36 and 60 in. from the top surface.)

IABLE 10. Comparison of Nitrite Leachability Index Summary Statistics for Pilot-Scale and Laboratory-Prepared 106-AN Grout Samples

\begin{tabular}{l} 
Nitrite Leachability Index(a) \\
$\begin{array}{l}\text { Laboratory } \\
\text { Prepared }\end{array} \quad$ Pilot-Scale \\
\hline
\end{tabular}

$\begin{array}{lcc}\text { Mean } & 7.90 & 7.23 \\ \text { Standard Deviation } & 0.26 & 0.24 \\ \text { Minimum } & 7.47 & 6.90 \\ \text { Maximum } & 8.33 & 7.90 \\ \text { Range } & 0.86 & 1.00 \\ \text { N } & 44 & 13\end{array}$

(a) Laboratory samples were cured 28 d at $65^{\circ} \mathrm{C}$; pilot-scale samples were cured 1 to $2 \mathrm{~m}$ in molds and $6 \mathrm{~m}$ at room temperature 
IABLE 11. Comparison of Nitrate Leachability Index Summary Statistics for Pilot-Scale and Laboratory-Prepared 106-AN Grout Samples

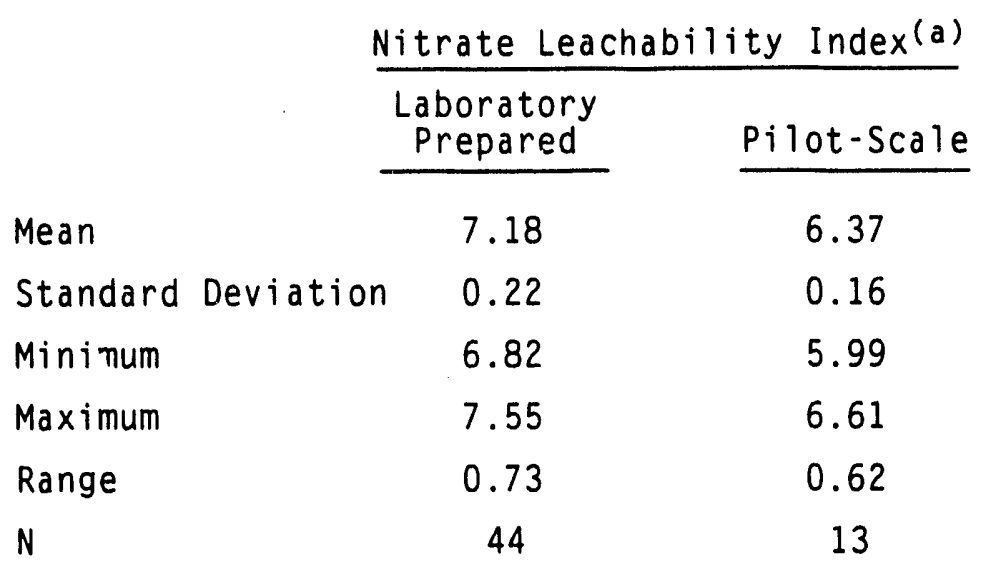

(a) Laboratory samples were cured 28 d at $65^{\circ} \mathrm{C}$; pilot-scale samples were cured 1 to $2 \mathrm{~m}$ in molds and $6 \mathrm{~m}$ at room temperature

\section{CORROSIVITY}

The corrosivity of three pilot-scale grout samples was determined using the WDOE Method 83-13 (WDOE 1984). The average pH of the solutions was 11.5. According to this procedure, a solid is considered corrosive if the solution has a pH of less than or equal to 2, or greater than or equal to 12.5. Therefore, the pilot-scale 106-AN grout would not be considered corrosive.

\section{MICROSTRUCTURE}

Scanning electron micrographs of fracture surfaces of pilot-scale grout samples are shown in Figures 9 through 12 . Three samples were from the gradient mold, and one from the fourth lift of the lift mold. The micrographs illustrate the typical morphology of the samples. The upper micrographs in the figures (500x magnification) reveal several features, including unreacted fly ash particles, fly ash particles coated with reaction products, remnants of air voids, and a large amount of porosity. The high magnification micrographs reveal the gel-like nature of the hydration reactions. A fly ash particle surrounded by a uniform layer of reaction product is seen in 


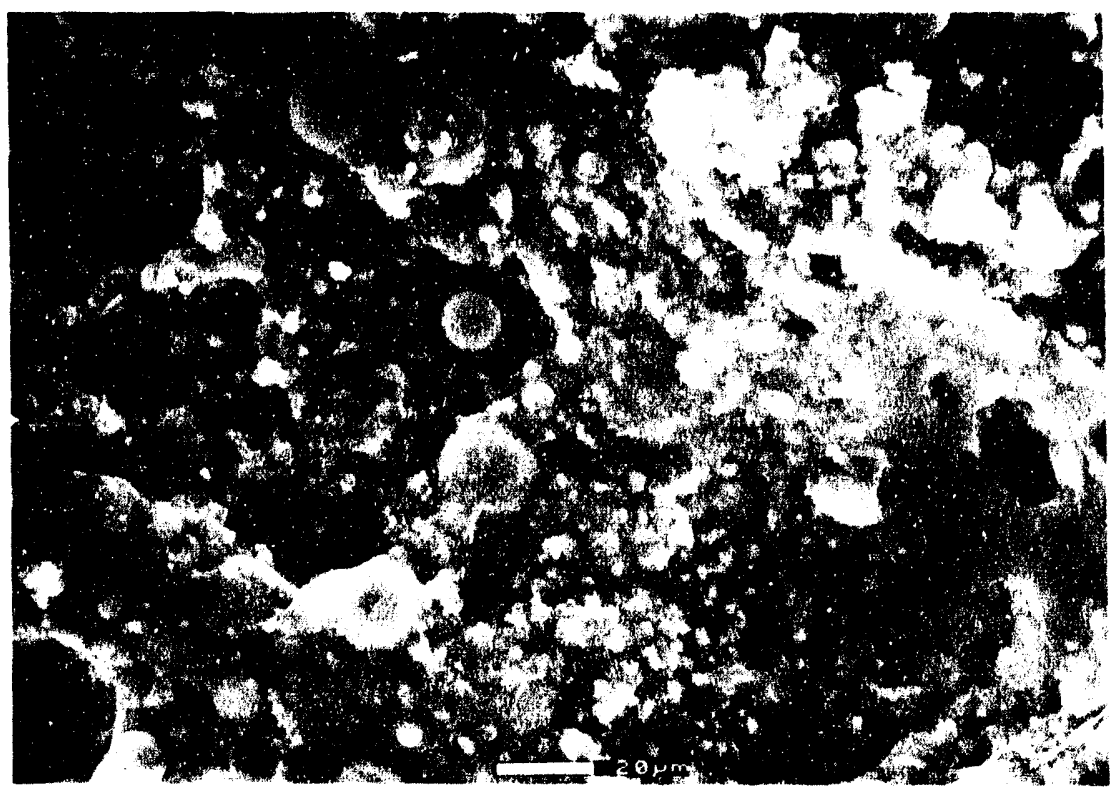

a

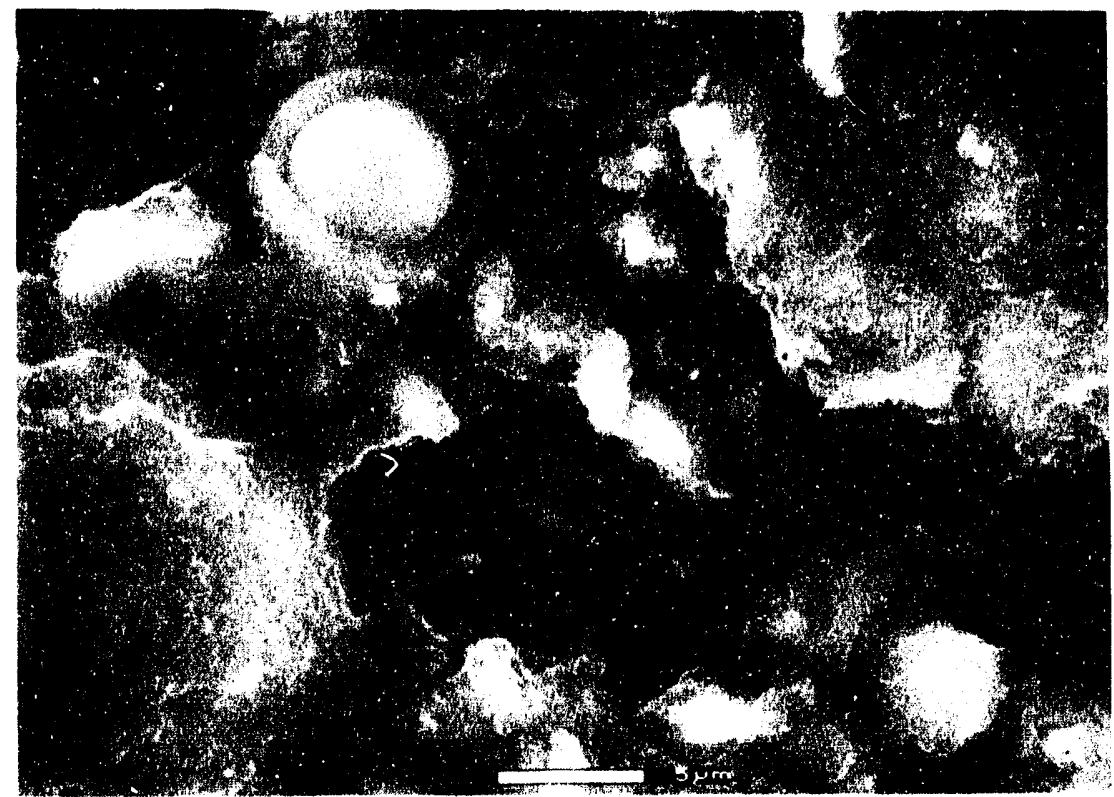

EIGURE 9. Environmental Scanning Electron Micrographs of 106-AN PilotScale Grout Core Samples Obtained 3-in. from the Edge of the Gradient Mold 


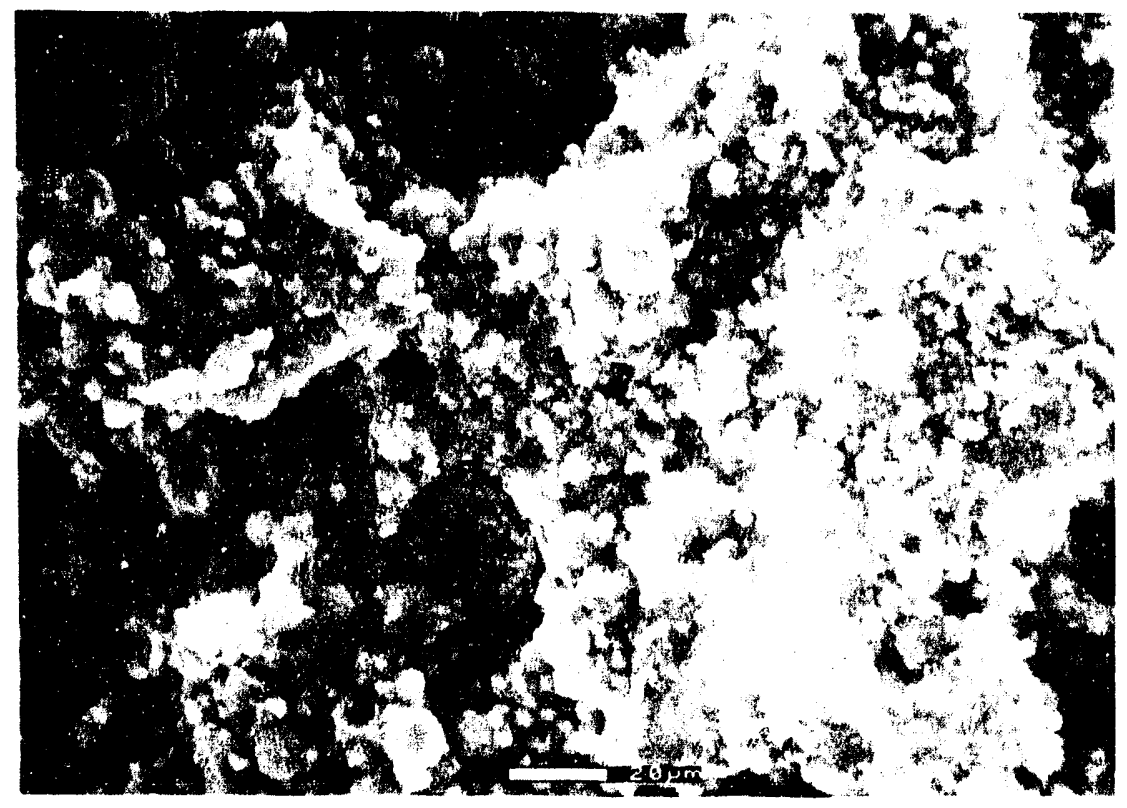

a

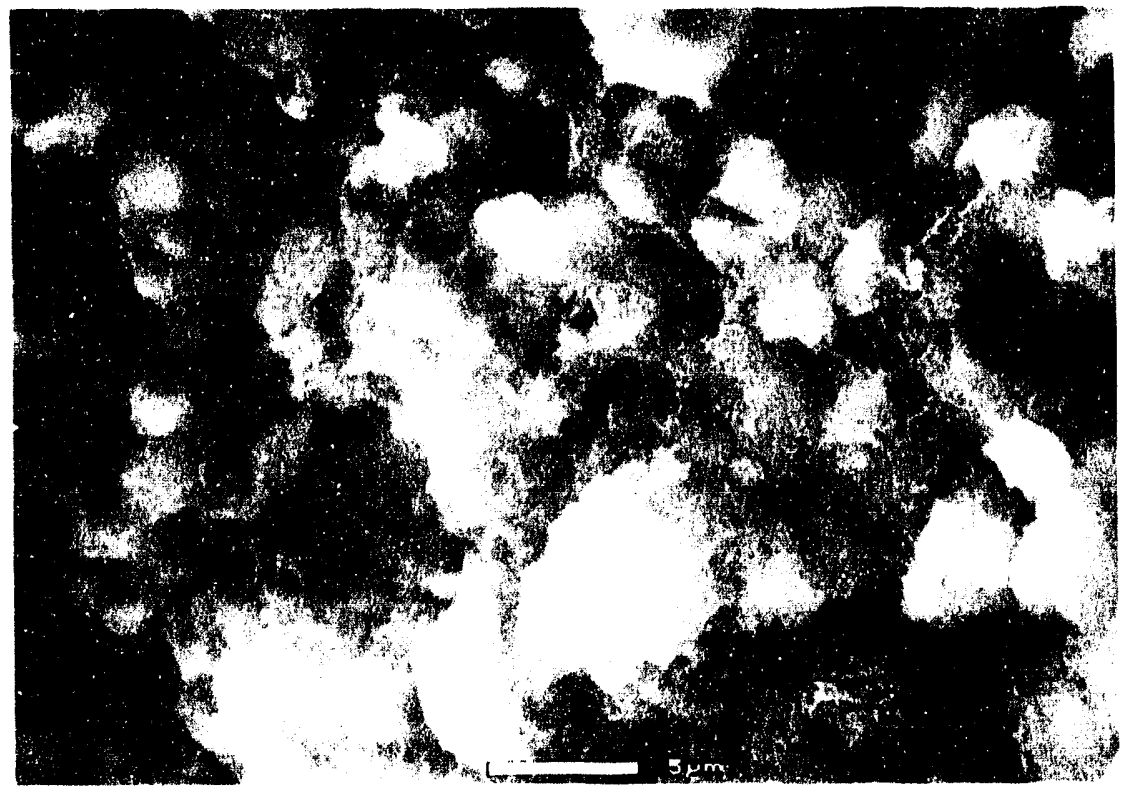

b

EIGURE 10. Environmental Scanning Electron Micrographs of 106-AN Pilot-Scale Grout Core Samples Obtained 12-in. from the Edge of the Gradient Mold 


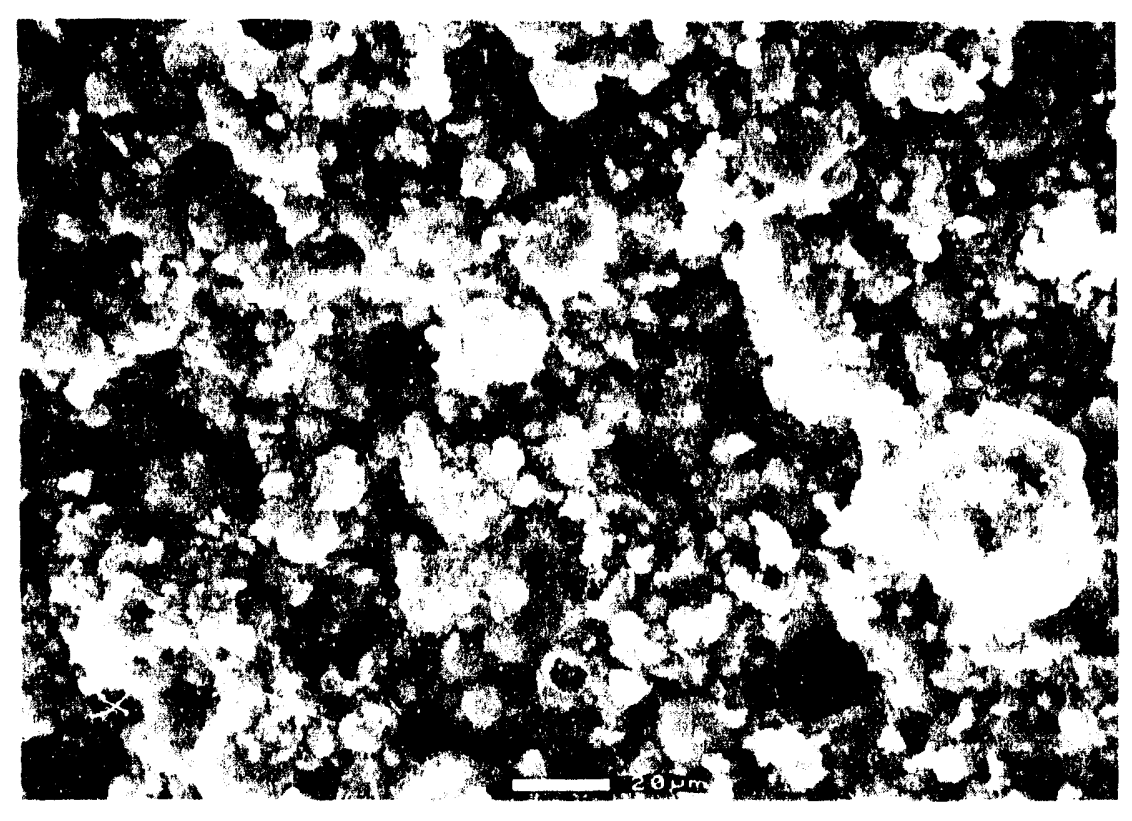

a

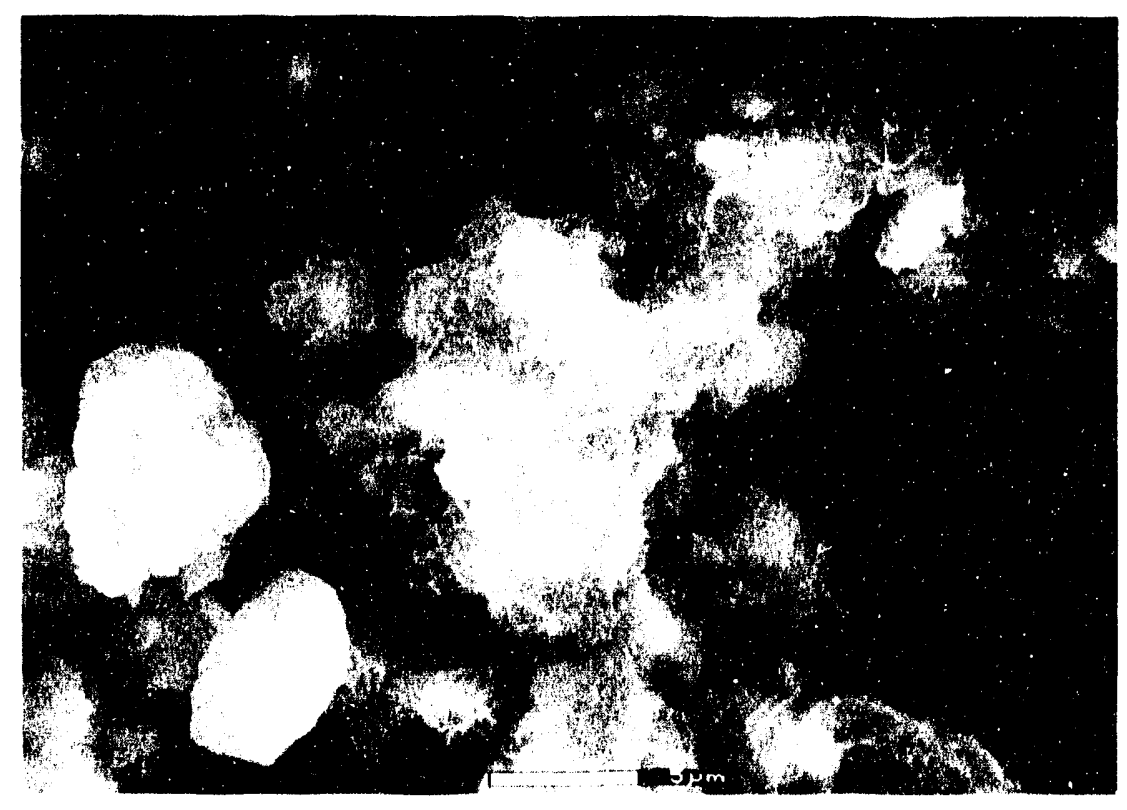

b

EIGURE 11. Environmental Scanning Electron Micrographs of 106-AN Pilot-Scale Grout Core Sample Obtained from the Centerline of the Gradient Mold 


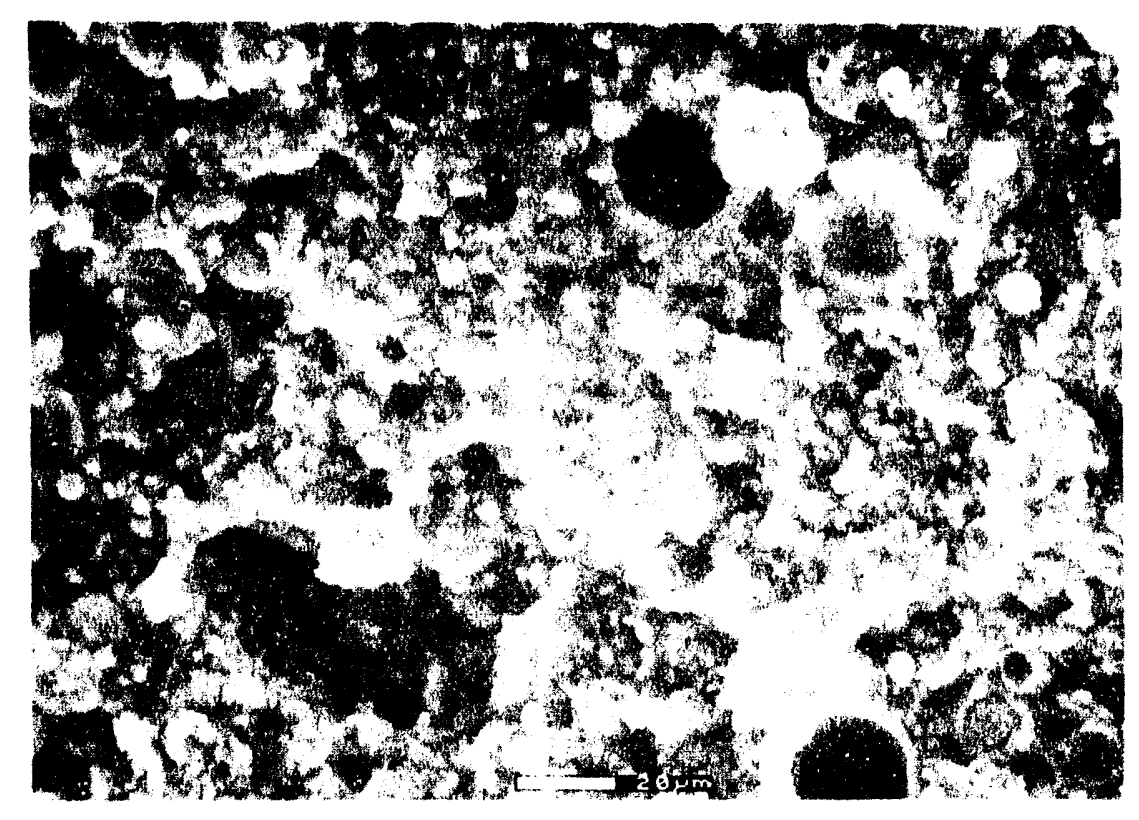

a

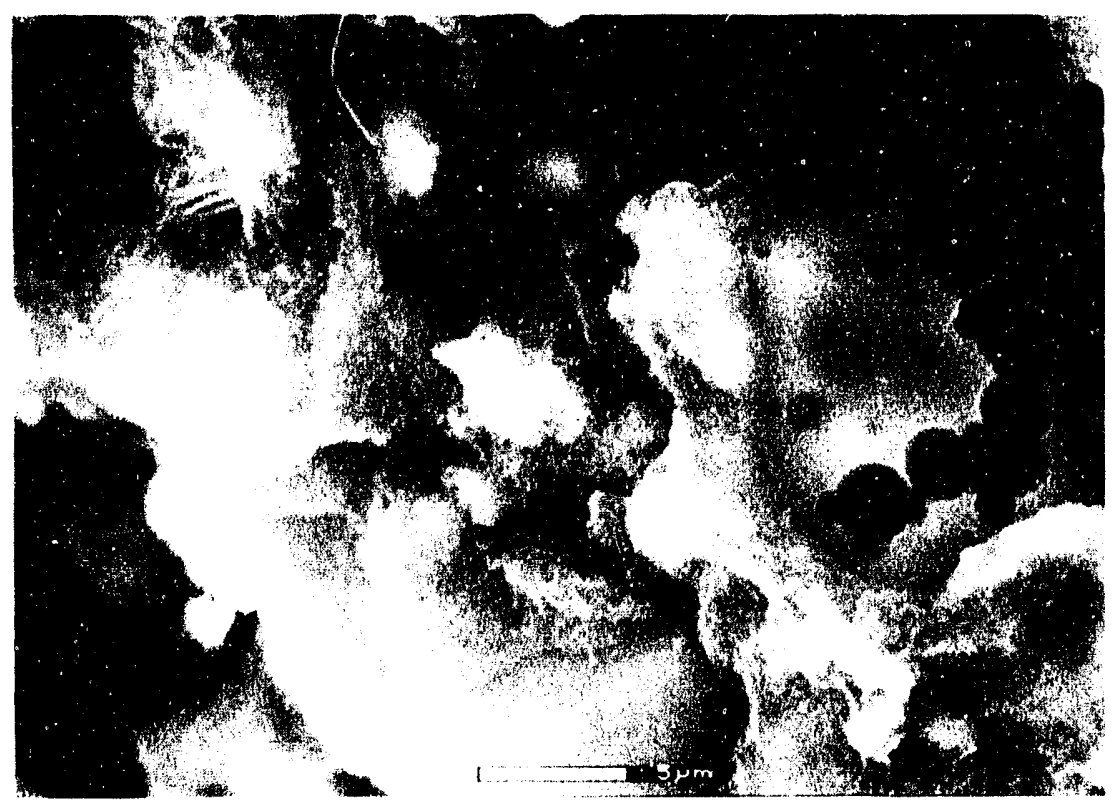

b

EIGURE 12. Environmental Scanning Electron Micrographs of 106-AN PilotScale Grout Core Sample Obtained Approximately 6-in. from the Top of the Lift Mold 


\section{REFERENCES}

American Nuclear Society (ANS). 1986. Measurement of the Leachability of Solidified Low-Level Radioactive Wastes by a Short-Term Test Procedure. ANSI/ANS 16.1-1986. American Nuclear Society, LaGrange Park. I1linois.

American Society for Testing and Materials (ASTM). 1985. 1985 Annual Book of ASTM Standards. Vo1. 4.02, Concrete and Mineral Aggregates, American Society for Testing and Materials. Philadelphia. Pennsylvania.

Bagasen. L. M. 1993. 106-ANGrout Pilot-Scale-Test. PNL-8618. Pacific Northwest Laboratory, Richland, Washington.

Cline. M. W.. A. R. Tedeschi and A. K. Yoakum. 1992. Phosphate/Sulfate Waste Grout Campaian Report. WHC-SD-WM-ER-059. Westinghouse Hanford Company. Richland, Washington.

Fow, C. L., D. H. Mitchel1, R. L. Treat, and C. R. Hymas, 1987. Pilot-Scale Grout Production Test with a Simulated Low-Level Waste. PNL-6148, Pacific Northwest laboratory, Richland, Washington.

Lokken, R. 0.. P. F. C. Martin, W. M. Bowen, H. Harty, R. L. Treat. 1987. Variability and Properties of Grouted Phosphate/Sulfate N-Reactor Waste. PNL6030. Pacific Northwest Laboratory. Richland. Washington.

Lokken, R. O.. P. F. C. Martin, L. C. Morrison, S. E. Palmer, C. M. Anderson. 1993. Eormulation Verification Study Results for 241-AN-106 Waste Grout.

PNL-8626. Pacific Northwest Laboratory. Richland. Washington.

Riebling. E. F. and J. G. Fadeff. 1991. Grout Formulation Standard Criteria. WHC-SD-WM-CSD-003. Westinghouse Hanford Company, Richland, Washington.

State of Washington Department of ECology (WDOE). 1984. "Chemical Testing Methods for Complying with the Dangerous Waste Regulation." Chapter 173-303. Washington Administration Code. State of Washington. Olympia. Washington. 


\section{DISTRIBUTION}

No. of

Copies

\section{QFESITE}

12 DOE/Office of Scientific and Technical Information

C. Frank, EM-50

DOE Office of Technology

Development

Trevion-II

128 Middlebrook Rd.

Germantown, MD 20874

4 DOE Office of Waste Operations

Trevion-II

12800 Middlebrook Rd.

Germantown. MD 20874

ATTN: J. A. Coleman, EM-35

M. W. Frei. EM-34

H. Harmon, EM-32

J. E. Lytie, EM-30

J. C. Haugen

DOE Chicago Operations office 9800 South Cass Avenue

Argonne, IL 60439

\section{F. Bazan}

Lawrence Livermore National Laboratory

University of California

P.0. Box 808

Livermore, CA 94550

5 Westinghouse Savannah River Company

Savannah River Site

Aiken, SC 29808-0001

ATTN: C. A. Langton

R. M. Wallace

E. Wilhite

E. Stevens

M. Hay
No. of

Copies

M. Fuhrmann

Brookhaven National Laboratory Upton. NY 11973

T. C. Johnson

Nuclear Regulatory Commission MS-623SS

Washington. DC 20555

M. McFadden

DOE Albuquerque Operations Office

P.0. Box 5400

Albuquerque. NM 87115

R. M. Neilson, Jr.

$E G \& G$

P.0. Box 1625

Idaho Falls, ID 83415

3 Oak Ridge National Laboratory P.0. Box X

Oak Ridge, TN 37831

ATTN: T.M. Gilliam

E. W. MCDaniel

R. D. Spence

E. B. Peacock

Wastech. Inc.

P.0. Box 1213

Oak Ridge, TN 37831-1213

D. M. Smith

University of New Mexico

Chemical and Nuclear

Engineering Depratment

A1buquerque. NM 87131 
No. of

Copies

FOREIGN

\section{A. Atkinson \\ Atomic Energy Research \\ Establ i shment \\ HARWELL \\ Didcot \\ Oxfordshire, OX 11 ORA \\ UNITED KINGDOM}

L. P. Buckley

Atomic Energy of Canada Ltd.

Chalk River, Ontario KOJ $1 J 0$

CANADA

P. Cote

Environment Canada

Canada Centre for Inland Waters

Burlington, Ontario LTR $4 A 6$

CANADA

\section{R. Dayal}

Ontario Hydro

800 Kipling Ave.

Toronto, Ontar:0 M8Z 5S4

CANADA

C. L. Farmer

Atomic Energy Establishment

WINFRITH

Dorchester, Dorset DT2 8DH

UNITED KINGDOM

\section{ONSITE}

DOE Richland Operations Office

K. W. Bracken

L. A. Huffman

G. H. Sanders
No. of

Copies

17 Westinghouse Hanford Company

K. W. Bledsoe

J. M. Connor

A. P. Hammitt

D. W. Hendrickson

A. A. Kruger

R. J. Murkowski

D. J. Newl and

W. J. Powell

E. F. Riebling

J. W. Shade

J. E. Van Beek

J. A. Voogd (4)

T. L. Welsh

G. F. Williamson

41 Pacific Northwest Laboratory

C. M. Anderson

C. R. Allen

L. M. Bagassen

K. A. Blanchard

R. G. Clemmer

R. E. Einziger

H. D. Freeman

B. M. Johnson

C. T. Kincaid

D. K. Kried

R. O. Lokken (10)

J. Leuy

K. R. Martin

P. F. C. Martin

G. L. McVay

R. K. Quinn

W. R. Ross

P. A. Scott

R. J. Serne

J. H. Westsik, Jr. (5)

G. A. Whyatt

K. D. Wiemers

Publishing Coodination

Technical Report Files 

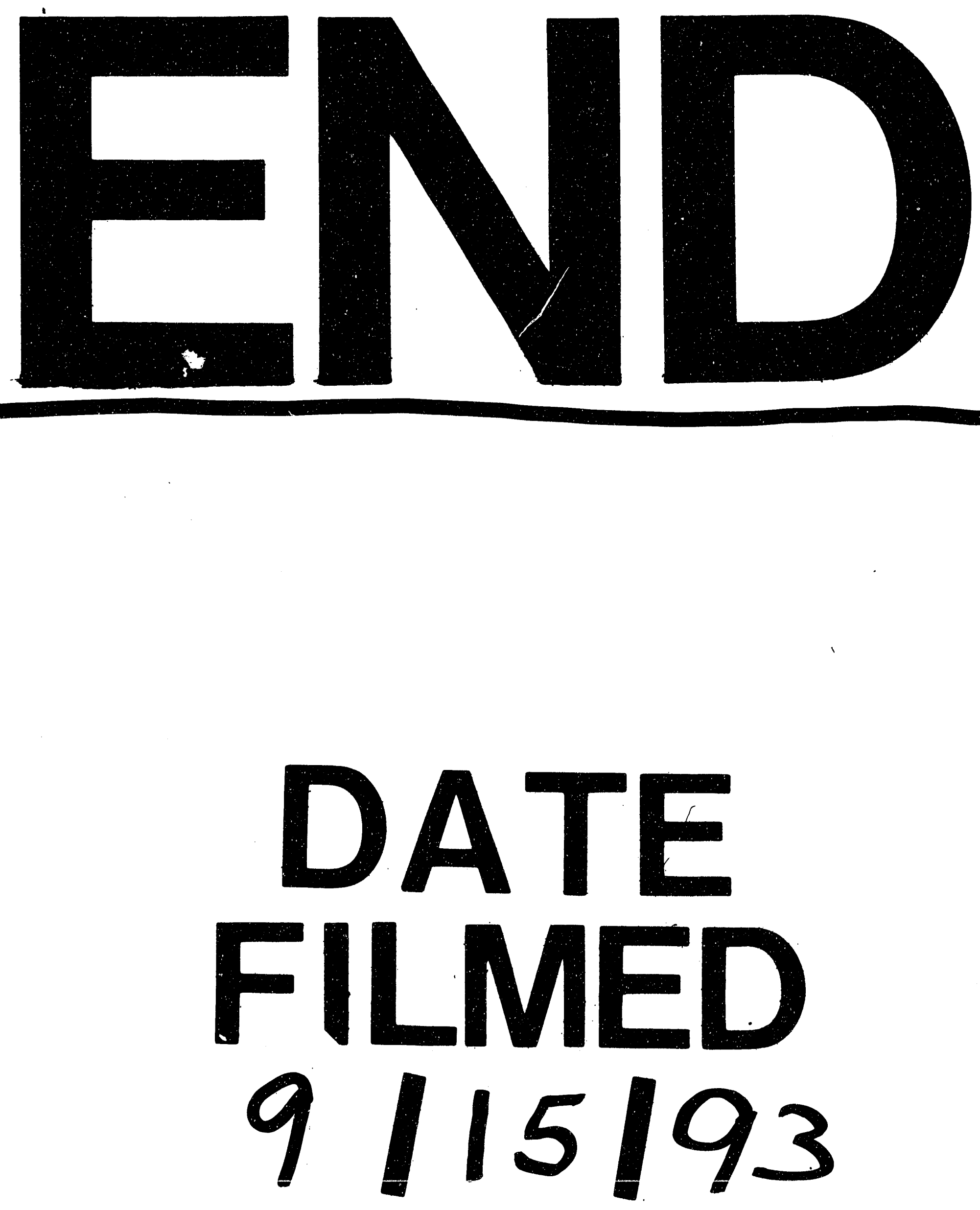


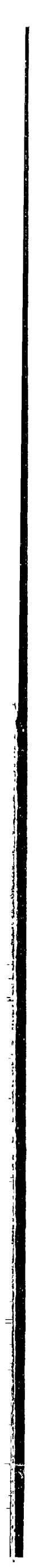

